\title{
Article \\ Do Terror Attacks Affect the Euro? Evidence from the 21st Century
}

\author{
Stelios Markoulis
}

check for

updates

Citation: Markoulis, Stelios. 2021. Do Terror Attacks Affect the Euro? Evidence from the 21st Century. Journal of Risk and Financial Management 14: 349. https:// doi.org/10.3390/jrfm14080349

Academic Editor: Vanja Piljak

Received: 6 July 2021

Accepted: 21 July 2021

Published: 30 July 2021

Publisher's Note: MDPI stays neutral with regard to jurisdictional claims in published maps and institutional affiliations.

Copyright: (C) 2021 by the author. Licensee MDPI, Basel, Switzerland. This article is an open access article distributed under the terms and conditions of the Creative Commons Attribution (CC BY) license (https:/ / creativecommons.org/licenses/by/ $4.0 /)$.
Cyprus International Institute of Management, Nicosia 2151, Cyprus; stelios.markoulis@ciim.ac.cy or markoulis.stelios@ucy.ac.cy

Abstract: The objective of this paper is to examine whether terror attacks that took place in the Eurozone in the 21st century had a significant effect on the price of the Euro. Its novelty is twofold: it is the first study that assesses the impact of such events on the price of the Euro and employs a relatively large number of these events. The event-study methodology is used to deduce whether, after a terror event, the value of the Euro declines vs. other major currencies. We found that it does not, since following such an event, the decline was seldom over $0.5 \%$. We also found, however, evidence of some diversion to safe-haven currencies, such as the Swiss Franc. Regression analysis revealed that factors such as the 'number of attacks', the 'type of target' and the 'type of attack', but not the number of casualties, affected the price of the Euro.

Keywords: event-study methodology; terrorism; foreign exchange market; Euro; market reaction

\section{Introduction}

There is little doubt that in the course of the 21st century so far, terrorism has emerged as an important international security issue. From a European perspective, in the last couple of decades, a number of terror attacks have targeted several European countries; well-known examples are the attacks in France (Paris in 2015 and Nice in 2016), Brussels (2016), Berlin (2016), and Barcelona (2017), among several others. Although the probability that an individual becomes a victim of such an attack is very low, by nature such events can change the perceptions of people, businesses and nations regarding their security, create uncertainty, reduce confidence, and breed populism and mistrust. Extensive media coverage of these events helps towards this direction by becoming a cohesive part of their impact mechanism. For example, the large-scale terror attacks that occurred between 2015 and 2017 in the EU made headlines for days across countries. From an economic perspective, the impact of the aforementioned events could potentially lead to lower levels of savings, investment, trade, and eventually economic growth, therefore affecting the currency of the country or region that was attacked. In the case of the EU, a study by the European Parliamentary Research Service (Ballegooij and Bakowski 2018) documents that, between 2004 and 2016, terrorism has cost the EU about EUR 5.6 billion in lost lives, injuries, and damage to infrastructure and around EUR 185 billion in lost GDP (EUR 88 billion of which occurred between 2013-2016).

A comprehensive IMF paper by Johnston and Nedelescu (2005) suggests that the impact of terror attacks on the economy of a country can be measured both in terms of direct and indirect costs. The former are mostly of a short-term nature and include the destruction of life and infrastructure while, the latter, which eventually could have a larger impact, may affect the economy by undermining consumer and investor confidence, which in turn may also affect the value of the currency. Regarding the indirect economic effects of terror attacks, Brück and Wickstrom (2004) argue that their eventual magnitude is likely to depend on factors such as the nature of the attack, the type of policies adopted in response to the attack, and the resilience of the markets of the affected country or economic union. Such resilience can be quite important in the context of the financial markets since 
one of their key functions following such a shock is to 'digest' the information contained therein and quickly and accurately 'price' it. From a fundamental perspective, once such an unexpected shock occurs, financial markets and market participants, such as investors and market analysts need to assess expectations regarding the economy, whether these expectations need to be revised downwards and to what extent. More specifically, as a result of a terror attack there might be a diversion of trade, a postponement of FDI, or a reduction in incoming visitors/tourists, thus causing a lower demand for the currency of the affected country/region, something that may lead to its possible depreciation in international markets. For instance, regarding tourism, Corbet et al. (2019) investigated the effect of terror attacks on European tourism through the response of the airline industry, documenting that tourism traffic flows are reduced despite substantial fare reductions. Unfortunately, for financial markets, including foreign exchange ones, the assessment of the threat of terrorism can be quite difficult. This threat can be thought of as an example of 'Knightian uncertainty' (Knight 1921), that is to say a risk that cannot be easily quantified and priced into asset values.

Motivated by the potentially negative effects of a terror attack on the economy and possibly on currency markets, the objective of this paper is to employ the event-study methodology to examine whether a number of major terror attacks that occurred in the Eurozone in the 21st century had an impact on the value of the Euro (i.e., decreased its price vs. that of other major currencies, such as the USD, the GBP, the JPY, and the CHF). Within this context, three additional issues are raised: (1) if there is indeed an impact, is this concentrated on the day of the attack or does a spillover occur beyond that day? (2) Do the effects of such attacks on the common currency differ between the first and second decades of the 21st century? Finally, (3) are there any specific attributes of terror attacks (e.g., the type of attack, number of attacks, number of casualties, type of target, and the extent of the damage) that may have more profound effects on the value of the common currency than others? By providing answers to the above questions, this study aims to contribute towards the broadening of the literature related to the effects of terror attacks on the Forex market, which, in contrast to the literature related to stock markets (e.g., Chen and Siems 2004; Brounen and Derwall 2010; Markoulis and Katsikides 2018; Papakyriakou et al. 2019), is rather scarce. Actually, to the best of our knowledge, with the exception of Hassapis et al. (2018) who examined the effect of a small number of terror attacks on the value of currencies including the Euro, it is the first comprehensive study that utilizes a relatively large sample of major terror attacks that occurred in the Eurozone, to examine the reaction of the common currency to such events. To better position our work, and for comparison purposes, our paper also analyzes the effect that the terror attack of 9/11 had on the U.S. Dollar (vs. the Euro, the British Pound, the Japanese Yen, and the Swiss Franc), as well as the effect that the London bombings of 7 July 2005 had on the Pound (vs. the Euro, the Dollar, the Yen, and the Franc).

The rationale behind the choice of the currencies mentioned above is related to the fact that the USD is considered to be the most important currency benchmark and the global reserve currency, but also the US, as well as the UK, is a large trade partner of the Eurozone; in 2019, according to the European Commission, the total trade with the US was EUR 616.386 million (15.2\% of total Eurozone trade) and with the UK it was EUR 511.798 million (12.6\% of total Eurozone trade). Regarding the Franc and the Yen, both Switzerland and Japan are also important trade partners of the EU (EUR 257.036 million and EUR 123.983 million, respectively) but also exhibit another important characteristic: these two currencies tend to remain relatively stable in times of turmoil or crisis and hence 'defend' investments from the adverse impact of currency risk. As such, it would be particularly interesting to examine whether, following a terror attack, which naturally causes uncertainty, the Euro depreciates vs. these two currencies, thus validating the above argument.

Generally speaking, our results indicate that such events do not affect the price of the Euro negatively, at least on average; the decline is rarely in excess of $0.5 \%$ vs. all four 
currencies, which is much lower than the decline the Dollar suffered as a result of $9 / 11$ (e.g., 1-day CAR vs. the Euro were -1.6\%). Having said that, it is important to note that we find some evidence that there is modest depreciation of the Euro vs. so-called safe-haven currencies, such as the Franc and to a lesser extent the Yen, especially during the second decade of the century. This may suggest some diversion from the Euro to these currencies. It is worth noting that we find that this same phenomenon was also evident in the case of 9/11 and the Dollar, and 7 July 2005 and the Pound. Our paper also benefited from regression analysis which unveiled that, factors such as the 'number of attacks' related to a particular event, the 'type of target' (i.e., civilian), and the 'type of attack' (i.e., bombing), but not the number of casualties, are likely to have an effect on the price of the Euro vs. the Dollar and the Pound.

The rest of the paper unfolds as follows: Section 2 presents an overview of existing literature and sets the research framework of this paper; Section 3 describes the data and the empirical method used; Section 4 presents our results; and Section 5 discusses the findings of our work and concludes the paper.

\section{Literature Review}

In recent decades and in particular after $9 / 11$, literature on the economic consequences of terrorism has grown considerably, with researchers either focusing on the broader economic impact of terror attacks or the effects of such incidents on financial markets. For example, Lenain et al. (2002) argued that terror attacks may affect the economy through three channels: higher trade costs; greater security and defence spending; and decreased insurance coverage. Abadie and Gardeazabal (2003) examined the economic impact of terrorist attacks on firms in the Basque Country, Spain, documenting that the stocks of firms with a significant part of their business in the Basque Country showed a positive relative performance when a truce was possible. In another paper, the same authors (Abadie and Gardeazabal 2008) examined the impact of terror attacks on foreign direct investment (FDI), indicating that there is a negative relationship between country terror-risk and the flow of FDI; flows of FDI are likely to affect the price of the currency through the demand-supply channel.

Bloomberg et al. (2004) also focused on the economic consequences of terrorism, documenting that the incidence of terrorism is negatively related to GDP growth; they find that a terror attack in a country is likely to reduce its GDP growth by $0.57 \%$ on average. Likewise, Gaibulloev and Sandler (2008) show that, in the period 1971-2004, terrorism has impaired economic growth in 18 Western European countries. Nitsch and Schumacher (2004) examined the effects of terrorism on trade flows and found that countries subject to terrorism tend to trade less with each other, while Schneider et al. (2014) argued that if a country suffers from frequent terror attacks, inflows of resources from other countries might be diverted externally towards other countries that are considered to be safer. In a more recent paper, Pham and Doucouliagos (2017) documented that terror attacks in a nation's neighboring countries significantly reduce bilateral trade. As in the case of FDI, the aforementioned can also have profound effects on the value of the currency of the country or region affected, as changes in trade patterns are likely to lead to changes in the demand for and supply of the currency, e.g., less exports could be accompanied with depreciation in the value of the currency.

Some studies have focused on the effect of terror attacks on different economic sectors. For instance, Raby (2003) documented that airline, travel, tourism, accommodation, restaurant, postal, and insurance industries are particularly sensitive to terrorism risks. Within this context, two industries that received special attention by researchers are tourism and airlines, where most studies point to a negative impact of terror incidents on both of these sectors: Drakos and Kutan (2003), Sloboda (2003), Fleischer and Buccola (2002) on tourism; Drakos (2004) and Ito and Lee (2004) on airline demand; and Markoulis and Neofytou (2019) on both. Again, such findings could have potentially important repercussions in 
the foreign exchange markets, such as less tourism and less demand for the currency of a country.

Moving now to the effect of terror attacks on financial markets, the majority of studies to date focus on the reaction of stock markets (rather than currency markets) to a relatively small number of well-known events. For example, Chen and Siems (2004) focused on the impact of 14 major events on the capital markets of the US, documenting that these have become more resilient over time and arguing that this could probably be explained by the more developed and stable US banking and financial sector. Actually, it is worth noting that in the aftermath of $9 / 11$, in order to offset the consequences of the attacks, the Fed increased short-term lending substantially and cut interest rates, while Congress approved a fiscal stimulus package of USD 40 billion to boost demand. Johnston and Nedelescu (2005) examined the reaction of markets to 9/11 and the attacks in Madrid in March 2004, pointing out that markets were not only affected from the major disruptions caused by extensive damage to property and communication systems (the 'direct' costs), but also by high levels of uncertainty, especially in the case of 9/11 (the 'indirect' costs). Arin et al. (2008) examined the effect of terror attacks on the behavior of the financial markets of six countries (Indonesia, Israel, Spain, Thailand, Turkey, and the UK), documenting that the magnitude of the effect was greater in emerging markets. Baumert (2009) examined the effect of 9/11, the Madrid bombings of 2004, and the London bombings of 2005 on US, European, and Japanese stock markets, pointing out that over time, the size of the impact of such events and their duration diminished due to the fact that investors measured more objectively the true economic repercussions and risks of such events. Chesney et al. (2011) examined terror attacks that occurred in 25 countries and their effect on stock, bond, and commodity markets, concluding that most of the attacks led to a significant negative impact on at least one market under consideration. Kollias et al. (2011) focused on the impact of the Madrid and London bombings on equity sectors, documenting significantly negative abnormal returns across the majority of sectors in the Spanish markets, but not so much in the case of the British markets, where the time of recovery was much faster. More recently, Markoulis and Katsikides (2018) examined the effect of 11 major terror attacks that occurred in the 21st century on international stock markets, documenting that, earlier events resulted in higher negative abnormal returns when compared to more recent ones. Where evident, these returns seemed to persist beyond the date of the event, but tended to disappear rather quickly. Finally, Papakyriakou et al. (2019) focused on terror acts in G7 countries for the period 1998-2017 and examined their impact on the stock market indices of 66 countries; the authors found that stock markets declined significantly on the day of the attack, as well as on the following trading day.

Despite the growing number of studies examining the economic impact of terror acts, the number of studies examining the effect of such events on foreign exchange markets remains rather limited. Eldor and Melnick (2004) examined how foreign exchange and stock markets reacted to terrorism in Israel, documenting that such attacks had a significant effect on both markets. Nonetheless, they also pointed out that, despite the attacks, financial markets continued to function efficiently. Maitah et al. (2017) studied the impact of terror attacks in Turkey and their effect on the Turkish Lira vs. the Pound (the authors selected the Pound as reference due to the size of British-based companies' investments in Turkey), documenting the existence of a relatively small negative impact, both in the short-run and the long-run (depreciation of $0.024 \%$ in the short-run and $0.0706 \%$ in the long-run). Narayan et al. (2017) examined how terrorist attacks affected the exchange rates of 21 countries against the Dollar, documenting varying reactions between countries in terms of magnitude and persistence. Hassapis et al. (2018) focused on the effect of major 21stcentury terror attacks on the foreign exchange market, documenting that, earlier events (e.g., 9/11 and the London and Madrid bombings, in 2004 and 2005, respectively) caused substantially negative event day returns, which seemed to persist for some days. Moreover, they pointed out that this finding appeared to be particularly evident in currency pairs which included the currency of the country attacked, and in the safe-haven currencies (i.e., 
the Yen and the Franc). In a more recent paper, Park and Khaleq (2018) analyzed a large number of terror attacks across the stock and foreign exchange markets of 36 countries from 1996 to 2015. Their analysis revealed that terror attacks had almost no impact on stock markets and a very small effect on foreign exchange markets. Moreover, the authors found that the number of fatalities slightly increased the likelihood of an adverse impact, while the number of wounded and the magnitude of recent attacks slightly decreased it.

\section{Data and Methodology}

A challenge when designing an event study on terrorist attacks is how to construct the sample of events that will be examined; in this paper we are interested in events that might be considered 'significant' and as such potentially affect financial markets and, more specifically, foreign exchange markets. As such, the definition given by the US Government's Incident Review Panel Criteria of what constitutes a 'significant' terror attack, is utilized. This states that a terrorist incident is considered to be significant 'if it results in loss of life or serious injury of persons, major property damage, and/or is an act or attempted act that could reasonably be expected to create the conditions 'if it results in loss of life or serious injury of persons, major property damage, and/or is an act or attempted act that could reasonably be expected to create the conditions noted ${ }^{1,2}$. Within the context of this definition, we collected from the Global Terrorism Database (GTD) ${ }^{3}$ data on all terror attacks which occurred in Eurozone countries during the period 2000-2017 and from these we selected those which fulfilled at least one of the following criteria: (a) more than 5 deaths; (b) more than 15 injured; and (c) the property damage was described to be 'major' in economic terms. We acknowledge that the selection criteria may be considered subjective but would like to note that, from the comprehensive literature review carried out in the previous section, there does not appear to be any specific method for selecting 'significant' events. On the contrary, studies seem to subjectively choose a typically small number of events that are best suited to address their research questions. We also believe that the aforementioned criteria 'connect' fairly well with the main research theme of our paper; for instance, terror attacks that result in injuries and deaths could 'scare away' tourists, which in turn may mean less demand for the currency, while terror attacks that cause major economic damage could affect or divert trade and investment flows, which again could result in negative repercussions for the currency.

After applying these criteria, we ended up with 63 event days ('attack-days'), which may reasonably be considered 'significant' and as such, may affect financial markets, including foreign exchange markets; we used the term event days rather than events, since on certain occasions, more than one event (attack) occurred on the same day (e.g., Brussels 2016). We should note here that one of the main differences between our work and that of other papers which have addressed the effect of terror attacks on financial markets, is that we cover a substantially larger number of events: Chen and Siems (2004) examined 14 events during the period 1915-2011; Johnston and Nedelescu (2005) examined two major events, 9/11 and the Madrid train bombings; and Baumert et al. (2013) focused on four significant events: 9/11; and the Madrid, London, and Boston bombings.

The full set of the event days selected is presented in Appendix A, while Figure 1 below depicts the number of event days per year over the period 2000-2017; our event days stop at the end of 2017, as this is the last year that the GTD reports information related to terror attacks. As can be seen, the first decade of the 21st century was characterized by a significant number of attacks every year, while the early part of the second decade was rather 'quiet' until 2015, when it peaked again with major attacks in countries such as France, Spain, Belgium, and Germany. It is worth noting that the perpetrators during the first decade were organizations such as Al-Qaida, as well as ones with a more local focus, such as the Basque Fatherland and Freedom (ETA), National Socialist Underground and Corsican National Liberation Front (FLNC), while in the second decade, the attacks were mostly carried out by the Islamic State of Iraq and the Levant (ISIL) and other Jihadi-inspired extremists. Regarding the type of attack, 46 out of the 74 attacks (which corresponded to 
the 63 event days) were bombings/explosions, while the total number of deaths from all 74 events was 532, with another 3593 wounded. We also noted that 26 events were related to attacks on 'business targets', 14 on 'private targets', and 13 on 'government-related targets', while the remaining 21 events were spread across transportation, religious, and military targets.

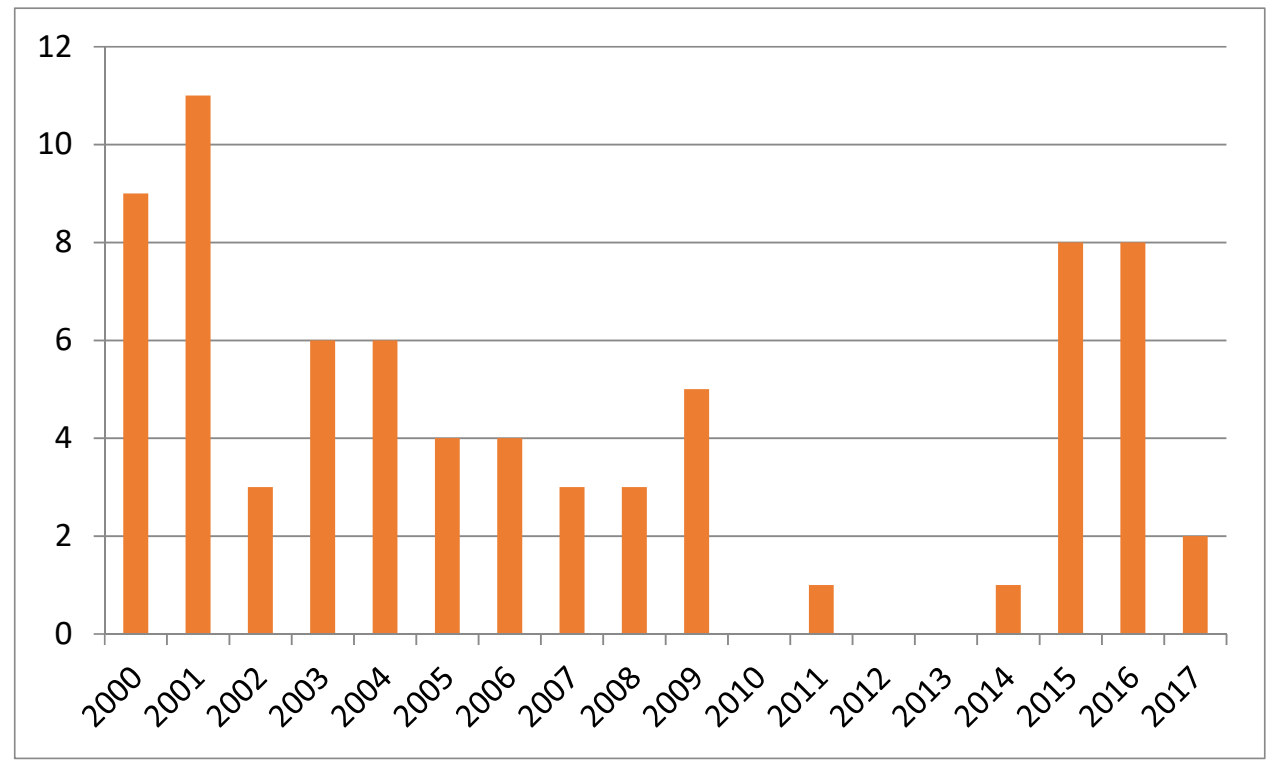

Figure 1. Terror attacks in Eurozone countries over the period 2000-2017. Notes: the above chart depicts a chronological breakdown of the 63 event days, which comprise our sample.

As already noted, the central research question examined in this paper refers to the potential effect that the terror attacks mentioned above had on the value of the common currency, the Euro, relative to four major global currencies: the USD, the JPY, the GBP, and the CHF. All data regarding the prices of the Euro relative to each of these four currencies, which are reported on a daily basis, were collected from the Forex Forum.

The prices of the four currency pairs were transformed into continuously compounded daily returns using Equation (1) below:

$$
R_{i t}=\ln \frac{P_{i t}}{P_{i t-1}}
$$

where: $R_{i t}$ are the daily returns of currency pair and $i, P_{i t}$ and $P_{i t}-1$ are the daily prices of currency pair $i$ (i.e., the Euro vs. each of the other four currencies) at time $t$ and $t-1$.

The methodology employed in this paper is the event-study methodology. Event studies examine the potential effects of one or more events on the prices of assets, such as stocks, bonds, commodities, and, in our case, currencies. The methodology is based on the efficient market hypothesis (EMH) (Fama 1970), which asserts that as new information arrives at the market, market participants immediately and accurately assess its current and future impact on prices, and that this assessment results in price changes which reflect the effect of this new information on the value of the asset. As such, significant price changes can be attributed to specific events, which resulted in the release of this new information.

Given the above property, over the years event studies have been broadly used in financial literature. The following list is by no means exhaustive, but some of the more important papers that have employed the event-study methodology are: Rendleman et al. (1982) and Ball and Brown (1968), to assess the impact of earnings announcements on stock prices; Brown and Warner (1980), Keown and Pinkerton (1981), and Bruner (1999), to assess the impact of M\&A announcements on stock prices; Teoh et al. (1998a, 1998b), to examine the phenomenon of earnings management; Loughran and Ritter (1995), to examine initial public offerings; Schwert (1981), to examine the effect of regulatory changes on stock prices; 
and Evans and Lyons (2008), to assess the effect of macroeconomic announcements on the foreign exchange market. As far as terror attacks are concerned, the work that has been done so far has primarily focused on the effect of terror attacks on stock markets; see for example, Chen and Siems (2004), Johnston and Nedelescu (2005), Baumert et al. (2013), Markoulis and Katsikides (2018), and Papakyriakou et al. (2019).

A general framework of the analysis that needs to be followed to design and carry out an event-study is provided in the seminal work of MacKinlay (1997) and Kothari and Warner (2007). Firstly, the date of the event needs to be determined; for the purposes of this work, this is the day on which the terror attack(s) took place. Next, as far as the time-series analysis is concerned, an 'estimation period' and an 'event period' need to be defined for each event. The former is the period that will be used to determine the estimated return predicted by the market around the event date, while, the latter is usually defined to be longer than the specific period of interest (i.e., the day of the event) to accommodate the examination of periods around the event. For the purposes of this paper, the 'estimation period' is set at 60 days and the 'event period' is set at 1,2,3,4, and 5 days, i.e., there are five event windows, including the day of the event. The event period is extended beyond the day of the incident to assess how quickly the market absorbed (or did not absorb) the news of the incident. On the one hand, it is plausible that on some occasions initial worries might persist (e.g., of further attacks), while, on the other hand, it is also possible that uncertainties might be quickly eased through the release of new information (e.g., the Government taking certain steps to comfort markets). This framework is described in Figure 2 below:

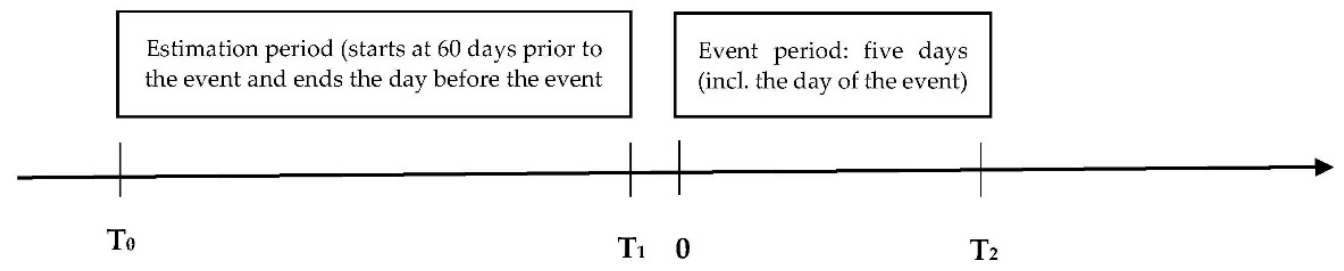

Figure 2. Event-Study Framework. Where the estimation period $\left(\mathrm{T}_{0}-\mathrm{T}_{1}\right)$, which starts 60 days before the event and ends one day prior to it, is used to provide estimates for the expected return of currency pair $i$ at time $t\left(E\left(R_{i t}\right)\right)$. This is related to Equations (2) and (3) below. The event period $\left(0-\mathrm{T}_{2}\right)$ which is 5 days including the day of the event denoted by 0 in the diagram, is used to obtain estimates for the abnormal (or excess) return of currency pair $i$ at time $t(A R i, t)$. This is related to Equations (2) and (4)-(7) below.

To measure the reaction of the Euro vs. each of the other four currencies to the announcement of a terror attack, an 'expected' return for each currency pair must be estimated during each event window. This 'expected' return must then be subtracted from the actual return, $R i, t$, observed during each event window, in order to determine whether there is any abnormal return that might have been caused by the specific event.

This abnormal return is given by the following equation:

$$
A R_{i t}=R_{i t}-E\left(R_{i t}\right)
$$

where: $A R_{i: t}=$ the abnormal (or excess) return of currency pair $i$ at time $t E\left(R_{i, t}\right)=$ the expected return of currency pair $i$ at time $t$.

An important element of the above equation is the estimation of the expected return of currency $i$ at time $t\left(E\left(R_{i, t}\right)\right)$, which is effectively the return we would expect, without the occurrence of the event. In this paper we follow the methodology used by Chen and Siems (2004), Baumert et al. (2013), and Markoulis and Katsikides (2018), and compute $E\left(R_{i, t}\right)$ as follows:

$$
E\left(R_{i: t}\right)=\frac{1}{60} \sum_{t=-60}^{-1} R_{i, t}
$$


The date of the event is $t=0$, hence the above equation estimates the expected return of currency pair i over the 60 trading days that preceded the event, i.e., from $t=-60$ to $t=-1$.

Following that, the cumulative abnormal returns (CAR) for currency pair $i$, for each event $j$, are estimated using the following equation:

$$
C A R_{j}=\left(t_{1}: t_{2}\right)=\sum_{t=t_{1}}^{t_{2}} A R_{i t}
$$

where: $t_{1}$ and $t_{2}$ are the start and end of each 'event window' for event $j$.

These CARs are then aggregated across all event days (i.e., $j=1$ to $N=63$ ) using Equation (5) and their variance is estimated by using Equation (6).

$$
\begin{gathered}
\operatorname{CAR}\left(t_{1}: t_{2}\right)=\frac{1}{N} \sum_{j=1}^{N} C_{A} R_{j}\left(t_{1}, t_{2}\right) \\
\sigma^{2} C A R\left(t_{1}: t_{2}\right)=\frac{1}{N^{2}} \sum_{j=1}^{N} \sigma^{2} C A R_{j}\left(t_{1}, t_{2}\right)
\end{gathered}
$$

where: $j$ is the $j$ th event and $N$ is the number of events examined.

Equations (5) and (6) can then be combined to construct a standard normally distributed test statistic, which is given by Equation (7).

$$
\operatorname{SCAR}\left(t_{1}: t_{2}\right)=\frac{\operatorname{CAR}\left(t_{1}, t_{2}\right)}{\left[\sigma^{2} C A R\left(t_{1}, t_{2}\right)\right]^{1 / 2}}
$$

where: $\operatorname{SCAR}\left(t_{1}, t_{2}\right)$ are the standardized CAR across events for each event window $\left(t_{1}\right.$ to $t_{2}$ ).

The aforementioned process enables aggregation both over time and across event days, in order to examine the hypothesis that the average cumulative abnormal return across all event days is zero, for each of the five event windows and for each of the four currency pairs examined.

\section{Results}

\subsection{Summary Statistics}

Table 1 presents the summary statistics of the CAR of the Euro for all event days, for each of the five event windows, and for each of the four currency pairs examined. An initial observation is that the mean CAR always results in a negative value, thus suggesting that the price of the Euro declines, at least to some extent, against all four currencies in all event windows. A further interesting observation is that in the 1- and 2-day event windows, the depreciation of the Euro vs. the Dollar and the Pound is larger vs. the Franc and the Yen (e.g., in the first event window it is $-0.14 \%$ and $-0.17 \%$ vs. $-0.03 \%$ and $-0.01 \%$ ) while in the latter event windows this is reversed (e.g., in the fifth event window it is $-0.18 \%$ and $-0.21 \%$ vs. $-0.56 \%$ and $-0.32 \%)$. The standard deviation of the CAR of the Euro across events appear to be at similar levels for the Dollar and the for all event windows; it

\begin{tabular}{|c|c|c|c|c|c|}
\hline \multicolumn{6}{|c|}{ Panel A: Euro vs. U.S. Dollar } \\
\hline & 1-Day & 2-Day & 3-Day & 4-Day & 5-Day \\
\hline Mean & -0.001425 & -0.001840 & -0.001759 & -0.001103 & -0.001796 \\
\hline Standard Error & 0.000719 & 0.000962 & 0.001257 & 0.001372 & 0.001654 \\
\hline Median & -0.000219 & -0.001792 & -0.001491 & -0.001351 & -0.002771 \\
\hline Standard Deviation & 0.005705 & 0.007636 & 0.009980 & 0.010890 & 0.013128 \\
\hline Sample Variance & 0.000033 & 0.000058 & 0.000100 & 0.000119 & 0.000172 \\
\hline Kurtosis & 1.021985 & 0.730133 & 0.374524 & 0.383464 & -0.127234 \\
\hline Skewness & -1.023363 & -0.319809 & 0.241420 & -0.071914 & 0.340992 \\
\hline
\end{tabular}
is slightly higher in the case of the Yen and quite higher in the case of the Franc, especially in the 3-, 4-, and 5-day event windows.

Table 1. Summary Statistics of CARs. 
Table 1. Cont

\begin{tabular}{|c|c|c|c|c|c|}
\hline \multicolumn{6}{|c|}{ Panel A: Euro vs. U.S. Dollar } \\
\hline & 1-Day & 2-Day & 3-Day & 4-Day & 5-Day \\
\hline Range & 0.025790 & 0.042075 & 0.051263 & 0.057173 & 0.061047 \\
\hline Minimum & -0.018570 & -0.024795 & -0.022675 & -0.027868 & -0.024881 \\
\hline Maximum & 0.007220 & 0.017280 & 0.028588 & 0.029305 & 0.036165 \\
\hline Count & 63 & 63 & 63 & 63 & 63 \\
\hline Largest(1) & 0.007220 & 0.017280 & 0.028588 & 0.029305 & 0.036165 \\
\hline Smallest(1) & -0.018570 & -0.024795 & -0.022675 & -0.027868 & -0.024881 \\
\hline \multicolumn{6}{|c|}{ Panel B: Euro vs. British Pound } \\
\hline & 1-Day & 2-Day & 3-Day & 4-Day & 5-Day \\
\hline Mean & -0.001668 & -0.002012 & -0.001352 & -0.001189 & -0.002156 \\
\hline Standard Error & 0.000644 & 0.001028 & 0.001405 & 0.001598 & 0.001661 \\
\hline Median & -0.001363 & -0.001743 & 0.000122 & -0.001772 & -0.001863 \\
\hline Standard Deviation & 0.005111 & 0.008157 & 0.011156 & 0.012686 & 0.013182 \\
\hline Sample Variance & 0.000026 & 0.000067 & 0.000124 & 0.000161 & 0.000174 \\
\hline Kurtosis & 0.864182 & 3.381466 & 1.450637 & 0.988410 & 0.149069 \\
\hline Skewness & -0.728716 & -0.825269 & -0.232505 & 0.176311 & 0.488522 \\
\hline Range & 0.024881 & 0.049281 & 0.065055 & 0.070677 & 0.060747 \\
\hline Minimum & -0.015775 & -0.034035 & -0.035161 & -0.038690 & -0.025158 \\
\hline Maximum & 0.009106 & 0.015245 & 0.029894 & 0.031987 & 0.035588 \\
\hline Count & 63 & 63 & 63 & 63 & 63 \\
\hline Largest(1) & 0.009106 & 0.015245 & 0.029894 & 0.031987 & 0.035588 \\
\hline Smallest(1) & -0.015775 & -0.034035 & -0.035161 & -0.038690 & -0.025158 \\
\hline \multicolumn{6}{|c|}{ Panel C: Euro vs. Swiss Franc } \\
\hline & 1-Day & 2-Day & 3-Day & 4-Day & 5-Day \\
\hline Mean & -0.000306 & -0.000487 & -0.002954 & -0.005379 & -0.005675 \\
\hline Standard Error & 0.000358 & 0.000503 & 0.002787 & 0.004121 & 0.004023 \\
\hline Median & -0.000249 & -0.000407 & -0.000468 & -0.000338 & 0.000339 \\
\hline Standard Deviation & 0.002840 & 0.003991 & 0.022121 & 0.032711 & 0.031931 \\
\hline Sample Variance & 0.000008 & 0.000016 & 0.000489 & 0.001070 & 0.001020 \\
\hline Kurtosis & 1.640068 & 0.103467 & 56.582240 & 26.484599 & 26.789406 \\
\hline Skewness & -0.164116 & 0.102934 & -7.330580 & -5.096993 & -5.108055 \\
\hline Range & 0.016409 & 0.019105 & 0.186441 & 0.224128 & 0.224902 \\
\hline Minimum & -0.009797 & -0.009227 & -0.171385 & -0.189561 & -0.189344 \\
\hline Maximum & 0.006613 & 0.009879 & 0.015057 & 0.034567 & 0.035558 \\
\hline Count & 63 & 63 & 63 & 63 & 63 \\
\hline Largest(1) & 0.006613 & 0.009879 & 0.015057 & 0.034567 & 0.035558 \\
\hline Smallest(1) & -0.009797 & -0.009227 & -0.171385 & -0.189561 & -0.189344 \\
\hline \multicolumn{6}{|c|}{ Panel D: Euro vs. Japanese Yen } \\
\hline & 1-Day & 2-Day & 3-Day & 4-Day & 5-Day \\
\hline Mean & -0.000168 & -0.001576 & -0.002425 & -0.000975 & -0.003184 \\
\hline Standard Error & 0.000989 & 0.001158 & 0.001609 & 0.001996 & 0.002233 \\
\hline Median & -0.000641 & -0.001016 & -0.003167 & -0.003339 & -0.003570 \\
\hline Standard Deviation & 0.007850 & 0.009188 & 0.012767 & 0.015841 & 0.017727 \\
\hline Sample Variance & 0.000062 & 0.000084 & 0.000163 & 0.000251 & 0.000314 \\
\hline Kurtosis & -0.103535 & 0.286812 & 0.679200 & 0.865768 & 1.537913 \\
\hline Skewness & 0.061345 & -0.167967 & -0.191675 & -0.090669 & -0.399309 \\
\hline Range & 0.037853 & 0.044986 & 0.065564 & 0.088846 & 0.108948 \\
\hline Minimum & -0.020294 & -0.024657 & -0.038611 & -0.045394 & -0.065170 \\
\hline Maximum & 0.017559 & 0.020329 & 0.026953 & 0.043452 & 0.043777 \\
\hline Count & 63 & 63 & 63 & 63 & 63 \\
\hline Largest(1) & 0.017559 & 0.020329 & 0.026953 & 0.043452 & 0.043777 \\
\hline Smallest(1) & -0.020294 & -0.024657 & -0.038611 & -0.045394 & -0.065170 \\
\hline
\end{tabular}

Notes: The above table presents summary statistics for the cumulative abnormal returns (CAR) of the EUR vs. the USD, the GBP, the CHF, and the JPY, across event days for all five event windows. 
Regarding skeweness and kurtosis, it appears that the vast majority of CAR over the event windows examined, lie within the normal distribution boundaries; generally speaking, \pm 2 is considered an 'acceptable limit' (see for example Trochim and Donnelly 2006; Field 2009; and Gravetter and Wallnau 2014). The only exception to this is related to the Franc in event windows three, four, and five.

Table 2 presents Pearson correlation coefficients between the CARs of the Euro vs. each of the four currencies, across event days, for all event windows. Generally speaking, we observed positive correlations, which nonetheless varied between currency pairs. For example, the EUR-USD CARs appear to be correlated more with the EUR-GBP and EURJPY and less so with the EUR-CHF. It is also worth mentioning the relatively low correlation between the EUR and GBP with the EUR-CHF and EUR-JPY CARs, as well as the stronger correlation between those of the EUR-CHF and EUR-JPY.

Table 2. Correlation Matrix of CARs.

\begin{tabular}{|c|c|c|c|c|}
\hline & USD 1-Day & GBP 1-Day & CHF 1-Day & Yen 1-Day \\
\hline USD 1-day & 1 & & & \\
\hline GBP 1-day & 0.481746989 & 1 & & \\
\hline CHF 1-day & 0.160796846 & 0.020198489 & 1 & \\
\hline \multirow[t]{2}{*}{ Yen 1-day } & 0.544607071 & 0.261428171 & 0.399784318 & 1 \\
\hline & USD 2-Day & GBP 2-Day & CHF 2-Day & Yen 2-Day \\
\hline USD 2-day & 1 & & & \\
\hline GBP 2-day & 0.502867971 & 1 & & \\
\hline CHF 2-day & -0.160294829 & 0.002262153 & 1 & \\
\hline \multirow[t]{2}{*}{ Yen 2-day } & 0.339631602 & 0.115735471 & 0.261462738 & 1 \\
\hline & USD 3-Day & GBP 3-Day & CHF 3-Day & Yen 3-Day \\
\hline USD 3-day & 1 & & & \\
\hline GBP 3-day & 0.471125988 & 1 & & \\
\hline CHF 3-day & 0.161140694 & 0.161435616 & 1 & \\
\hline \multirow[t]{2}{*}{ Yen 3-day } & 0.533600477 & 0.19541001 & 0.399522869 & 1 \\
\hline & USD 4-Day & GBP 4-Day & CHF 4-Day & Yen 4-Day \\
\hline USD 4-day & 1 & & & \\
\hline GBP 4-day & 0.454317633 & 1 & & \\
\hline CHF 4-day & 0.262107642 & 0.28165626 & 1 & \\
\hline \multirow[t]{2}{*}{ Yen 4-day } & 0.544993501 & 0.201486654 & 0.487340332 & 1 \\
\hline & USD 5-Day & GBP 5-Day & CHF 5-Day & Yen 5-Day \\
\hline USD 5-day & 1 & & & \\
\hline GBP 5-day & 0.594090817 & 1 & & \\
\hline CHF 5-day & 0.217968671 & 0.273640909 & 1 & \\
\hline Yen 5-day & 0.552119629 & 0.387566705 & 0.35793853 & 1 \\
\hline
\end{tabular}

Notes: The above table presents Pearson correlation coefficients between the cumulative abnormal returns (CAR) of the EUR vs. the USD, the GBP, the CHF, and the JPY, across event days for all five event windows.

\subsection{Event-Study Results}

In this section, we present the main body of the findings of our research: the results of the event-study analysis. More specifically, Table 3 below presents the mean CAR and standard errors of all event days analyzed for each currency pair, and for each of the five event windows. The table also depicts the corresponding t-statistics and $p$-values; the null hypothesis tested is whether the mean CAR are equal to zero across event days (i.e., the price of the Euro did not change significantly as a result of the attack), while the alternative hypothesis is that it is less than zero (i.e., the Euro depreciates vs. the other currencies). 
Table 3. Event-Study Results (full period).

\begin{tabular}{|c|c|c|c|c|c|}
\hline \multicolumn{6}{|c|}{ Panel A: Euro vs. U.S. Dollar } \\
\hline Event Window & {$[0,1]$} & {$[0,2]$} & {$[0,3]$} & {$[0,4]$} & {$[0,5]$} \\
\hline Mean excess return & -0.001425 & -0.001840 & -0.001759 & -0.001103 & -0.001796 \\
\hline Standard error & 0.000719 & 0.000962 & 0.001257 & 0.001372 & 0.001654 \\
\hline t-statistic & -1.982971 & -1.912204 & -1.399127 & -0.803894 & -1.085662 \\
\hline$p$-value & 0.025903 & 0.030237 & 0.083379 & 0.212265 & 0.140916 \\
\hline \multicolumn{6}{|c|}{ Panel B: Euro vs. British Pound } \\
\hline Event Window & {$[0,1]$} & {$[0,2]$} & {$[0,3]$} & {$[0,4]$} & {$[0,5]$} \\
\hline Mean excess return & -0.0016677 & -0.002011501 & -0.001352393 & -0.00118901 & -0.002156171 \\
\hline Standard error & 0.000643921 & 0.00102764 & 0.001405463 & 0.001598267 & 0.001660789 \\
\hline t-statistic & -2.58991357 & -1.957398239 & -0.962240582 & -0.743937088 & -1.298281222 \\
\hline$p$-value & 0.005974875 & 0.027403051 & 0.169833368 & 0.229862371 & 0.09949971 \\
\hline \multicolumn{6}{|c|}{ Panel C: Euro vs. Swiss Franc } \\
\hline Event Window & {$[0,1]$} & {$[0,2]$} & {$[0,3]$} & {$[0,4]$} & {$[0,5]$} \\
\hline Mean excess return & -0.000305817 & -0.000486589 & -0.002954402 & -0.005378957 & -0.005675202 \\
\hline Standard error & 0.000357777 & 0.000502876 & 0.002787008 & 0.004121141 & 0.00402288 \\
\hline t-statistic & -0.854771672 & -0.96761271 & -1.060062103 & -1.30521055 & -1.410731155 \\
\hline$p$-value & 0.197984264 & 0.168498651 & 0.146614312 & 0.098322188 & 0.081660931 \\
\hline \multicolumn{6}{|c|}{ Panel D: Euro vs. Japanese Yen } \\
\hline Event Window & {$[0,1]$} & {$[0,2]$} & {$[0,3]$} & {$[0,4]$} & {$[0,5]$} \\
\hline Mean excess return & -0.000168 & -0.001576 & -0.001759 & -0.000975 & -0.003184 \\
\hline Standard error & 0.000989 & 0.001158 & 0.001257 & 0.001996 & 0.002233 \\
\hline t-statistic & -0.169908 & -1.361687 & -1.399127 & -0.488308 & -1.425547 \\
\hline$p$-value & 0.432818 & 0.089112 & 0.083379 & 0.313527 & 0.079507 \\
\hline
\end{tabular}

Notes: The above table presents the mean cumulative abnormal return and standard error of all event days, for each currency pair, and for each event window for the whole period 2000-2017. The table also depicts the corresponding $\mathrm{t}$-statistics and $p$-values; the null hypothesis tested is whether the mean excess returns are equal to zero across the events, while the alternative hypothesis is that the mean excess returns across events are less than zero.

For the first event window [0, 1], the mean CAR of the Euro, across all event days examined, are negative against all four currencies, with the effect being more pronounced in the case of the Dollar $(-0.14 \%)$ and the Pound $(-0.17 \%)$. In actuality, in the case of these two currencies, the depreciation of the Euro is statistically significant at the $5 \%$ and $1 \%$ levels, respectively, while, in the case of the Franc and the Yen, results are not significant. Results are quite similar for the next event window [0,2] as far as the Dollar and the Pound are concerned; negative and significant CAR of $-0.18 \%$ and $-0.20 \%$, respectively. Moreover, in relation to this event-window, it is also important to note that the CAR of the Euro vs. the Yen decrease significantly, relative to the $[0,1]$ window, from $-0.01 \%$ to $-0.16 \%$, and actually becomes statistically significant at the $10 \%$ level.

In the third event window [0,3], patterns appear to change with mean CAR for the Dollar and the Pound, becoming less negative, i.e., the Euro recovers, and less statistically significant. The Euro vs. the Pound CAR become insignificant, while the Euro vs. the Dollar CAR maintain their significance, albeit at a 10\% level. The Euro vs. the Franc CAR remain insignificant, while, as in the case of the $[0,+2]$ window, the Euro vs. the Yen CAR increase $(-0.18 \%)$ and remain significant at the $10 \%$ level. In the fourth event window $[0,4]$, the Euro vs. the Dollar CAR and the Euro vs. the Pound CAR increase further (i.e., become less negative) and are both insignificant; while the Euro vs. Franc CAR become more negative $(-0.54 \%)$ and significant at the $10 \%$ level and the Euro vs. the Yen CAR are not significant. Finally, in the fifth event window, the Euro vs. the Dollar CAR remain insignificant, while the CAR for the three other currency pairs are significant at the $10 \%$ level; it is worth noting the higher magnitude of the negative Euro vs. Franc CAR $(-0.57 \%)$ against the other two currency pairs. 
Results regarding all CAR are summarized in Figure 3 and reveal some interesting patterns. It seems that, in the cases of the Dollar and the Pound, more negative CAR are more evident in the earlier event windows $([0,1],[0,2])$, while in the cases of the Franc and the Yen we observe higher negative CAR in the latter event windows, particularly in the final one $[0,5]$. All in all, it seems that the Euro depreciates more vs. the Dollar and the Pound in the earlier event windows, while in the latter event windows, the depreciation vs. the Yen and the Franc is more evident. Nonetheless, it should be noted that the statistical significance of the Dollar and Pound results is relatively stronger.

For comparative purposes, we also analyzed two additional important events, which occurred in the 21st century, but outside the Eurozone. These are the 9/11 attacks in the USA and its impact on the value of the Dollar (vs. the Euro, the Pound, the Franc and the Yen) and the $7 / 7$ attack in the UK and its impact on the value of the Pound (vs. the Euro, the Dollar, the Franc and the Yen) $)^{4}$. Our results are depicted in Table 4 below.

Table 4. Analysis of the effect of the 11 September 2001 attack in the USA (on the USD) and the 7 July 2005 attack in the UK (on the GBP).

\begin{tabular}{|c|c|c|c|c|c|}
\hline 9/11-Attack in the & & & & & \\
\hline Event Window & {$[0,1]$} & {$[0,2]$} & {$[0,3]$} & {$[0,4]$} & {$[0,5]$} \\
\hline \multicolumn{6}{|l|}{ USD vs. Euro } \\
\hline CAR & -0.015680 & -0.006160 & -0.011029 & -0.020869 & -0.024461 \\
\hline$p$-value & 0.023310 & 0.528611 & 0.356968 & 0.131167 & 0.113531 \\
\hline \multicolumn{6}{|l|}{ USD vs. Pound } \\
\hline CAR & -0.011368 & -0.005306 & -0.006448 & -0.006364 & -0.002264 \\
\hline$p$-value & 0.013821 & 0.416522 & 0.420155 & 0.490776 & 0.826438 \\
\hline \multicolumn{6}{|l|}{ USD vs. Yen } \\
\hline CAR & -0.013156 & -0.011150 & -0.017872 & -0.031287 & -0.027203 \\
\hline$p$-value & 0.023616 & 0.175003 & 0.075878 & 0.007119 & 0.036360 \\
\hline \multicolumn{6}{|l|}{ USD vs. CHF } \\
\hline CAR & -0.026978 & -0.013716 & -0.019603 & -0.034373 & -0.045268 \\
\hline$p$-value & 0.000082 & 0.156895 & 0.098564 & 0.012125 & 0.003129 \\
\hline \multicolumn{6}{|c|}{ 7/7-Attack in the UK } \\
\hline Event Window & {$[0,1]$} & {$[0,2]$} & {$[0,3]$} & {$[0,4]$} & {$[0,5]$} \\
\hline \multicolumn{6}{|l|}{ GBP vs. USD } \\
\hline CAR & -0.005024 & -0.008704 & 0.005323 & 0.017221 & 0.007165 \\
\hline$p$-value & 0.271254 & 0.177724 & 0.500910 & 0.059331 & 0.482866 \\
\hline \multicolumn{6}{|l|}{ GBP vs. Euro } \\
\hline CAR & -0.008126 & -0.014158 & -0.011311 & -0.013845 & -0.013179 \\
\hline$p$-value & 0.044718 & 0.013405 & 0.106722 & 0.087288 & 0.145427 \\
\hline \multicolumn{6}{|l|}{ GBP vs. Yen } \\
\hline CAR & -0.006904 & -0.010315 & -0.000579 & 0.002497 & 0.001763 \\
\hline$p$-value & 0.093720 & 0.076619 & 0.935289 & 0.761844 & 0.848245 \\
\hline \multicolumn{6}{|l|}{ GBP vs. CHF } \\
\hline CAR & -0.009802 & -0.010315 & -0.011142 & -0.013095 & -0.008994 \\
\hline$p$-value & 0.006461 & 0.007490 & 0.073900 & 0.068892 & 0.263767 \\
\hline
\end{tabular}

Notes: The above table presents the cumulative abnormal return and $p$-values of the U.S. Dollar and the British Pound, for each currency pair, and for each event window as a result of the $9 / 11$ and $7 / 7$ attacks, respectively. The null hypothesis tested is whether the cumulative excess returns are equal to zero, while the alternative hypothesis is that they are less than zero.

As might be observed from the table, as a result of the $9 / 11$ attack, the Dollar depreciated vs. all four currencies; the magnitude of the depreciation is higher on average than the one we documented in our analysis regarding the Euro and increases when looking at the Yen and the Franc $(-2.7 \%$ and $-4.5 \%$, respectively, in the $[0,5]$ event-window). This nonetheless may be an expected outcome, given the shocking magnitude and severity of 
the 9/11 attack. Moreover, it is very interesting to note that the depreciation of the Dollar vs. the Euro and the Pound is statistically significant only in the $[0,1]$ event window, while depreciation of the Dollar against the Yen and the Franc seems to be more persistent, as results appear to be significant in four out of the five event windows. Generally speaking, these findings bear some interesting similarities to our analysis, given that the adjustment vs. the Euro and the Pound happens early on while depreciation vs. the Yen and the Franc (the safe-haven currencies) seem to be more persistent and cumulatively higher.

Turning now to the $7 / 7$ attack, it is very interesting to note that there is no significant negative adjustment of the Pound vs. the Dollar, while there is little downward adjustment vs. the Yen, which nonetheless is significant at the $10 \%$ level in the first two event windows. There is, nonetheless, greater and more persistent depreciation of the Pound vs. the Euro and the Franc. Again, these findings have some similarities to our analysis regarding the Euro in the sense that they validate both the adjustment vs. the Euro (contrastingly, in our analysis, the Euro depreciates vs. the Pound) and the depreciation vs. the safe-haven currencies, in particular the Franc. In actuality, both the 9/11 and 7/7 attacks seem to verify the fact that after a shock, such as a terror attack, the Dollar and the Pound seem to appreciate lending support, at least to some extent, to the safe-haven currencies.

The analysis in this section provides important insights regarding the first two research questions addressed in this paper. The first question asked whether significant terror attacks that took place in the Eurozone affected the value of the Euro vs. the four other major currencies. Results seem to suggest that they do, but the effect, although statistically significant in several instances, is not large in magnitude or uniform across the currencies; for example, the maximum negative average CAR for the EUR vs. the USD are $-0.184 \%$, which occur in the $[0,3]$ event window, while the maximum negative average CAR documented are $-0.57 \%$ vs. the $\mathrm{CHF}$ in the $[0,5]$ event window. The second question asked whether the reaction occurred only on the day of the event or spilled over to the following days; results seem to indicate this effect, especially in the case of the Euro and the Yen. This latter finding is consistent with our analysis of the two non-Eurozone events which verify the depreciation of the USD and the GBP vs. the CHF and the JPY. It is also in the spirit of earlier studies which document the negative effect of terror attacks on the stock markets and their prices, not only on the day of the attack but also in the following days (see Chen and Siems 2004; Baumert et al. 2013; and Markoulis and Katsikides 2018).

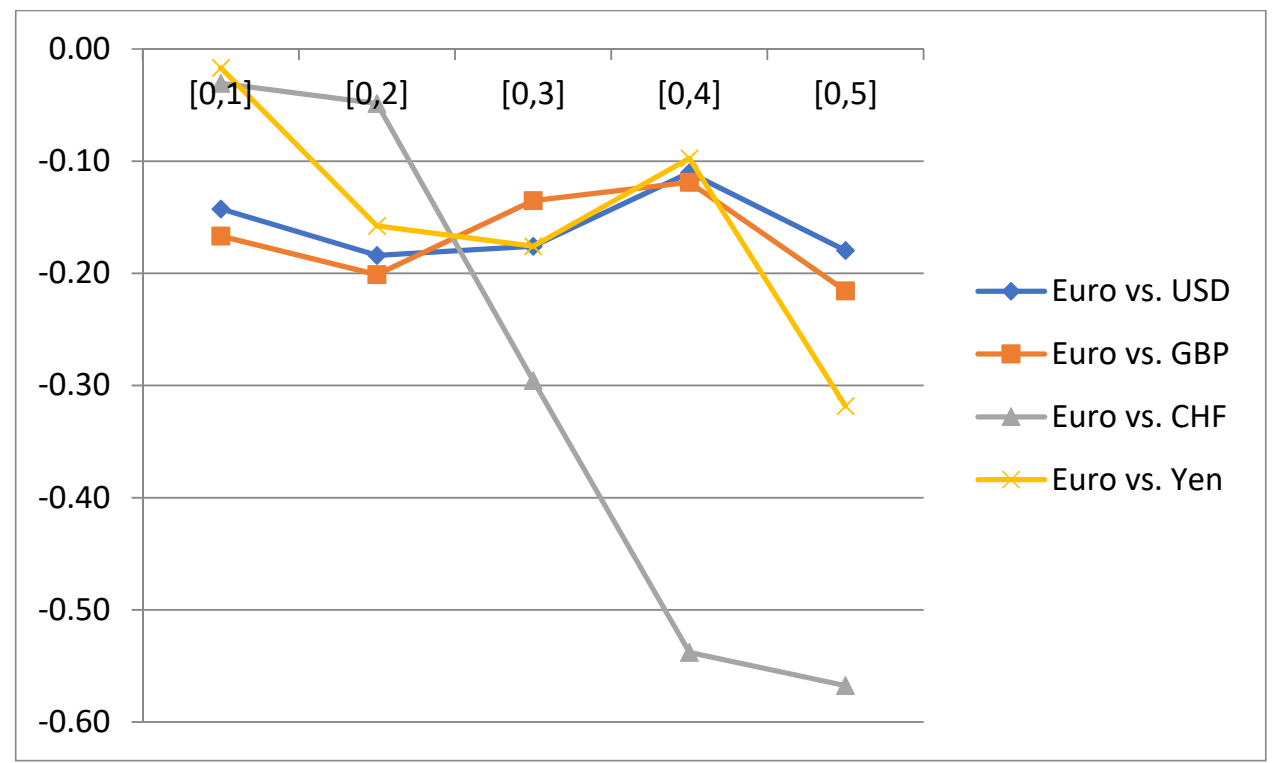

Figure 3. Summary of Results-Mean CAR (\%). Notes: the above chart depicts mean CAR for all event days and for all currency pairs, across all five event windows. 
We next divide our sample into two time periods: 2000-2010 and 2011-2017, in an attempt to explore whether the reaction of the Euro vs. the four currencies examined was different over time. Given the different nature of the perpetrators in the first decade (mainly Al-Qaida and localized organizations) and second decade (mainly Jihadi-inspired) of the 21st century, it is plausible that different patterns may emerge. Results are depicted in Table 5A,B and reveal some interesting findings. More specifically, in the case of the Euro vs. the Dollar, the negative CAR are higher in the first decade and also exhibit stronger statistical significance; mean CAR are significant in two of the five event windows in the first decade ( $5 \%$ level), but only one in the second decade (10\% level). Similar results are depicted for the Euro vs. the Pound, where the negative CAR are significant in three of the five event windows (various significance levels) for the first sub-period, while in the second sub-period there are no significant results. Results are quite different in the case of the Franc and the Yen. The negative CAR of the Franc are higher in the second sub-period and significant in three of the five event windows while the negative CAR of the Yen are higher in the second sub-period and significant in four of the five event windows. In actuality, it is worth noting the relatively high CAR of the Yen vs. the Franc in the [0,4] and $[0,5]$ event windows $(-2.63 \%$ and $-2.53 \%$, respectively, at the $10 \%$ level $)$. In summary, to address the third research question examined in this paper, which asked whether the effect of terror attacks on the common currency varies between the first and second decades of the 21st century, it seems that, as far as the EUR vs. the USD and the GBP are concerned, the negative CAR are more evident and statistically significant during the period 2000-2010 while, in the case of the EUR vs. the CHF and the JPY, the situation is clearly reversed.

Table 5. (A). Event-Study Results (first sub-period: 2000-2010). (B). Event-Study Results (second sub-period: 2010-2017).

(A)

\begin{tabular}{|c|c|c|c|c|c|}
\hline \multicolumn{6}{|c|}{ Panel A: Euro vs. U.S. Dollar } \\
\hline Event Window & {$[0,1]$} & {$[0,2]$} & {$[0,3]$} & {$[0,4]$} & {$[0,5]$} \\
\hline Mean excess return & -0.001500 & -0.002071 & -0.001832 & -0.000894 & -0.002002 \\
\hline Standard error & 0.000895 & 0.001202 & 0.001549 & 0.001657 & 0.001986 \\
\hline t-statistic & -1.676184 & -1.723246 & -1.182782 & -0.539767 & -1.007796 \\
\hline$p$-value & 0.050226 & 0.045695 & 0.122359 & 0.297235 & 0.160564 \\
\hline \multicolumn{6}{|c|}{ Panel B: Euro vs. British Pound } \\
\hline Event Window & {$[0,1]$} & {$[0,2]$} & {$[0,3]$} & {$[0,4]$} & {$[0,5]$} \\
\hline Mean excess return & -0.002057615 & -0.002711014 & -0.001463583 & -0.001594853 & -0.002576656 \\
\hline Standard error & 0.000678467 & 0.001201019 & 0.001635176 & 0.001849169 & 0.00193392 \\
\hline t-statistic & -3.032739838 & -2.257262054 & -0.895061383 & -0.862470567 & -1.332349117 \\
\hline$p$-value & 0.001717027 & 0.013918703 & 0.1889848 & 0.197755463 & 0.095246127 \\
\hline \multicolumn{6}{|c|}{ Panel C: Euro vs. Swiss Franc } \\
\hline Event Window & {$[0,1]$} & {$[0,2]$} & {$[0,3]$} & {$[0,4]$} & {$[0,5]$} \\
\hline Mean excess return & $3.1447 \times 10^{-5}$ & -0.000468041 & $-9.865 \times 10^{-5}$ & 0.000606749 & $-6.21251 \times 10^{-5}$ \\
\hline Standard error & 0.000373204 & 0.000585189 & 0.000699151 & 0.001037172 & 0.00106045 \\
\hline t-statistic & 0.084262337 & -0.799810323 & -0.141099827 & 0.585003499 & -0.058583713 \\
\hline$p$-value & 0.466511662 & 0.212897686 & 0.44404337 & 0.279958934 & 0.476702729 \\
\hline \multicolumn{6}{|c|}{ Panel D: Euro vs. Japanese Yen } \\
\hline Event Window & {$[0,1]$} & {$[0,2]$} & {$[0,3]$} & {$[0,4]$} & {$[0,5]$} \\
\hline Mean excess return & 0.000346 & -0.000837 & -0.001302 & 0.000634 & -0.001881 \\
\hline Standard error & 0.001167 & 0.001375 & 0.001799 & 0.002244 & 0.002518 \\
\hline t-statistic & 0.296521 & -0.609039 & -0.723726 & 0.282794 & -0.747121 \\
\hline$p$-value & 0.384910 & 0.274063 & 0.237804 & 0.390096 & 0.230750 \\
\hline
\end{tabular}


Table 5. Cont.

(B)

\begin{tabular}{|c|c|c|c|c|c|}
\hline \multicolumn{6}{|c|}{ Panel A: Euro vs. U.S. Dollar } \\
\hline Event Window & {$[0,1]$} & {$[0,2]$} & {$[0,3]$} & {$[0,4]$} & {$[0,5]$} \\
\hline Mean excess return & -0.001166 & -0.001032 & -0.001505 & -0.001833 & -0.001074 \\
\hline Standard error & 0.000860 & 0.001069 & 0.001709 & 0.002208 & 0.002769 \\
\hline t-statistic & -1.355663 & -0.965012 & -0.880290 & -0.830475 & -0.387805 \\
\hline$p$-value & 0.093433 & 0.171715 & 0.193383 & 0.206916 & 0.350658 \\
\hline \multicolumn{6}{|c|}{ Panel B: Euro vs. British Pound } \\
\hline Event Window & {$[0,1]$} & {$[0,2]$} & {$[0,3]$} & {$[0,4]$} & {$[0,5]$} \\
\hline Mean excess return & -0.000302996 & 0.000436795 & -0.000963229 & 0.000231442 & -0.000684475 \\
\hline Standard error & 0.00166306 & 0.001852205 & 0.002797286 & 0.003230101 & 0.003263214 \\
\hline t-statistic & -0.182191765 & 0.235824232 & -0.344344168 & 0.071651545 & -0.209755002 \\
\hline$p$-value & 0.428422662 & 0.407708416 & 0.366678563 & 0.471713774 & 0.417746928 \\
\hline \multicolumn{6}{|c|}{ Panel C: Euro vs. Swiss Franc } \\
\hline Event Window & {$[0,1]$} & {$[0,2]$} & {$[0,3]$} & {$[0,4]$} & {$[0,5]$} \\
\hline Mean excess return & -0.001486243 & -0.000551509 & -0.012949534 & -0.02632893 & -0.02532097 \\
\hline Standard error & 0.000899675 & 0.0010007 & 0.012267977 & 0.01752681 & 0.017164496 \\
\hline t-statistic & -1.651978114 & -0.551123049 & -1.05555576 & -1.502208901 & -1.475194512 \\
\hline$p$-value & 0.055283437 & 0.29312734 & 0.150440724 & 0.07254617 & 0.076084104 \\
\hline \multicolumn{6}{|c|}{ Panel D: Euro vs. Japanese Yen } \\
\hline Event Window & {$[0,1]$} & {$[0,2]$} & {$[0,3]$} & {$[0,4]$} & {$[0,5]$} \\
\hline Mean excess return & -0.001968 & -0.004163 & -0.006356 & -0.006606 & -0.007743 \\
\hline Standard error & 0.001750 & 0.001916 & 0.003490 & 0.004159 & 0.004802 \\
\hline t-statistic & -1.124673 & -2.172795 & -1.821082 & -1.588240 & -1.612424 \\
\hline$p$-value & 0.135502 & 0.019548 & 0.040061 & 0.062160 & 0.059472 \\
\hline
\end{tabular}

Notes Panel A: The above table presents the mean CAR and standard error of all event days for each currency pair, and for each event window for the period 2000-2010. The table also depicts the corresponding t-statistics and $p$-values. The null hypothesis tested is whether the mean excess returns are equal to zero across events, while the alternative hypothesis is that the mean excess returns across events are less than zero. Notes Panel B: The above table presents the mean CAR and standard error of all event days for each currency pair, and for each event window for the period 2011-2017. The table also depicts the corresponding t-statistics and $p$-values. The null hypothesis tested is whether the mean excess returns are equal to zero across events, while the alternative hypothesis is that the mean excess returns across events are less than zero.

Following the above, we added another dimension to our analysis by examining a sub-sample of our data containing only the event days, which resulted in deaths. It is plausible that such events could be considered as more severe and hence affect markets more, mostly through the negative psychology channel. For example Eldor and Melnick (2004) and Eldor et al. (2012) documented that the effect of terror attacks on the stock markets increased as the number of casualties and fatalities increased. A limitation related to this aspect of our work, is that the number of event days in our sample is relatively small (16 event days). Interestingly, regarding the EUR vs. the USD and GBP CAR, we did not find any significant results (i.e., the Euro did not seem to depreciate significantly following an attack which resulted in loss of life). Regarding the EUR vs. the JPY and CHF, we found evidence of significant negative CAR for event window [0,5] and event windows [0, 4] and $[0,5]$, respectively, albeit only at the $10 \%$ level of significance ${ }^{5}$. Thus, again we have evidence of the safe haven currencies appreciating vs. the Euro, but from another angle, the currencies related to attacks that resulted in casualties.

\subsection{Regression Analysis}

In this section we expand our analysis further by carrying out OLS regressions, in an attempt to examine possible cross-sectional differences in CAR for each event window 
and for each currency pair. The following set of potential explanatory variables is used. Information regarding these variables has also been collected from the GTD:

Type of attack ('Type'): If the attack was a bombing/explosion $=1$ and, if otherwise, $=0$. We would expect bombings/explosions to lead to higher negative CAR, since they are potentially more upsetting and could therefore affect market psychology more negatively.

Number of attacks in the same event day ('>1 target'): If more than one $=1$ and, if otherwise, $=0$. We would expect more than one attack on the same event day to possibly be associated with higher negative CAR due to potentially greater damage, as well as more negative market psychology.

Number of Deaths: The number of deaths as a result of the attack. We would expect a greater number of casualties to be associated with more negative CAR, primarily due to negative market sentiment, e.g., visitors not traveling to a country which experienced such an attack. Note that the effect of such attacks could be magnified through mass media coverage.

Number of Wounded: The number of wounded as a result of the attack. The same logic and expectation as expressed above is applicable.

Type of target ('Target'): If the attack was on a civilian target $=1$ and, if otherwise, $=0$. We would expect attacks on civilian targets to be associated with more negative CAR since they are likely to affect broader masses of people, both locally and internationally, increasing their sense of insecurity, something that could also lead to negative economic consequences.

Damage ('Damage') ${ }^{6}$ : If the damage is categorized as 'major' by GTD $=1$ and, if otherwise, $=0$. We would expect attacks that cause major economic damage to be associated with more negative CAR.

Table 6 below presents our results. To preserve space we only reported the Euro vs. the Dollar (panel A) and the Euro vs. the Pound (panel B) results, since those related to the Franc and the Yen did not reveal any statistically significant results.

Results in the first panel of the table seem to indicate that 'the number of attacks' variable comes out as statistically significant in three of the five event windows (the first three) and its consistently negative value suggests that event days that are associated with more than one attack lead to lower CAR for the Euro vs. the Dollar; the magnitude of the difference in CAR varies, from $-0.67 \%$ in the 1 -day event window, to $-1.37 \%$ in the 3 -day event window. The next variable that is significant, again in three of the five event windows (the last three), is 'target'; its negative sign indicates that when attacks were directed at civilian targets, there was greater depreciation for the Euro vs. the Dollar, ranging from $-0.47 \%$ in the 3 -day event window, to $-0.83 \%$ in the 5 -day event window.

The second panel of the table reveals that the 'type' of attack variable is significant in all of the event windows, except for the first one. More specifically, results suggest that if the type of attack was a bombing or explosion, the CAR of the Euro vs. the Pound were more negative. These range from CAR of $-0.44 \%$ in the $[0,2]$ to $-0.85 \%$ in the $[0,5]$ event windows.

Overall, our analysis in this section indicates that specific characteristics of each event may lead to differences in the reaction of the Euro, relative to the Dollar and the Pound, which may lead to the depreciation of the common currency by up to $1.37 \%$. It would appear that events that spread fear and that are extensively covered by the mass media, such as bombings, attacks on civilian targets, and attacks on more than one target, cause more concern and psychological unrest and thus lead to depreciation of the common currency. 
Table 6. (A). Cross-Sectional Regression Analysis of the Euro vs. the Dollar CAR. (B). Cross-Sectional Regression Analysis of the Euro vs. the Pound CAR.

\section{(A)}

\begin{tabular}{|c|c|c|c|c|}
\hline \multicolumn{5}{|l|}{ Event Window $[0,1]$} \\
\hline & Coefficients & Standard Error & t Stat & $p$-Value \\
\hline Intercept & -0.002287596 & 0.001807869 & -1.265354433 & 0.210984036 \\
\hline Type (bombing $=1$ ) & 0.001906494 & 0.001748467 & 1.090380361 & 0.280215269 \\
\hline$>1$ target & $-0.006766891^{* *}$ & 0.003349998 & -2.01996858 & 0.048180694 \\
\hline Deaths & $3.6335 \times 10^{-5}$ & $6.42862 \times 10^{-5}$ & 0.565206839 & 0.5741906 \\
\hline Wounded & $3.64866 \times 10^{-6}$ & $7.94985 \times 10^{-6}$ & 0.458959149 & 0.64804 \\
\hline Target $($ civilian $=1)$ & -0.000474583 & 0.001616217 & -0.293637941 & 0.770120114 \\
\hline Damage (Major = 1) & -0.000263407 & 0.001838837 & -0.143246237 & 0.886609918 \\
\hline \multicolumn{5}{|l|}{ Event Window $[0,2]$} \\
\hline & Coefficients & Standard Error & t Stat & $p$-Value \\
\hline Intercept & 0.000715045 & 0.002442539 & 0.2927464 & 0.770798002 \\
\hline Type (bombing $=1$ ) & -0.001607149 & 0.002362283 & -0.680337285 & 0.499094123 \\
\hline$>1$ target & $-0.007963593^{*}$ & 0.004526047 & -1.759502724 & 0.083954103 \\
\hline Deaths & $2.72825 \times 10^{-5}$ & $8.68545 \times 10^{-5}$ & 0.314117204 & 0.754599255 \\
\hline Wounded & $2.86554 \times 10^{-6}$ & $1.07407 \times 10^{-5}$ & 0.266791774 & 0.790609487 \\
\hline Target $($ civilian $=1)$ & -0.003063358 & 0.002183605 & -1.402890165 & 0.166169734 \\
\hline Damage (Major = 1) & -0.000155325 & 0.002484379 & -0.062520797 & 0.950370722 \\
\hline \multicolumn{5}{|l|}{ Event Window $[0,3]$} \\
\hline & Coefficients & Standard Error & t Stat & $p$-Value \\
\hline Intercept & 0.00288501 & 0.003038893 & 0.949362439 & 0.346515553 \\
\hline Type (bombing $=1$ ) & 0.000118063 & 0.002939041 & 0.040170573 & 0.968100013 \\
\hline$>1$ target & $-0.013693186^{* *}$ & 0.005631095 & -2.431709191 & 0.018251577 \\
\hline Deaths & $-7.92577 \times 10^{-5}$ & 0.00010806 & -0.733458313 & 0.466338496 \\
\hline Wounded & $2.02606 \times 10^{-5}$ & $1.33631 \times 10^{-5}$ & 1.516157563 & 0.135104444 \\
\hline Target $($ civilian $=1)$ & -0.005027384 * & 0.002716739 & -1.850521627 & 0.069515955 \\
\hline Damage (Major $=1$ ) & -0.003307935 & 0.003090947 & -1.070200826 & 0.289120041 \\
\hline \multicolumn{5}{|l|}{ Event Window $[0,4]$} \\
\hline & Coefficients & Standard Error & t Stat & $p$-Value \\
\hline Intercept & 0.00277096 & 0.003402329 & 0.81443032 & 0.418848431 \\
\hline Type (bombing $=1$ ) & -0.001548528 & 0.003290535 & -0.470600616 & 0.639753844 \\
\hline$>1$ target & -0.006956199 & 0.006304546 & -1.103362417 & 0.274588735 \\
\hline Deaths & -0.000147942 & 0.000120984 & -1.222826429 & 0.226516625 \\
\hline Wounded & $2.35434 \times 10^{-5}$ & $1.49613 \times 10^{-5}$ & 1.573621594 & 0.121208279 \\
\hline Target $($ civilian $=1)$ & $-0.006344338^{* *}$ & 0.003041647 & -2.085822871 & 0.041562797 \\
\hline Damage $($ Major $=1)$ & $1.40757 \times 10^{-5}$ & 0.003460609 & 0.004067411 & 0.996769139 \\
\hline \multicolumn{5}{|l|}{ Event Window $[0,5]$} \\
\hline & Coefficients & Standard Error & t Stat & $p$-Value \\
\hline Intercept & 0.00476179 & 0.004118102 & 1.156307151 & 0.252464739 \\
\hline Type $($ bombing $=1$ ) & $-9.45649 \times 10^{-5}$ & 0.003982789 & -0.023743381 & 0.981141707 \\
\hline$>1$ target & -0.008765538 & 0.007630879 & -1.14869309 & 0.255565497 \\
\hline Deaths & -0.000114103 & 0.000146436 & -0.779204173 & 0.439140008 \\
\hline Wounded & $2.19478 \times 10^{-5}$ & $1.81088 \times 10^{-5}$ & 1.211998004 & 0.230602154 \\
\hline Target $($ civilian $=1)$ & $-0.008742423 * *$ & 0.003681541 & -2.374664109 & 0.021015963 \\
\hline Damage $($ Major $=1)$ & -0.004136941 & 0.004188643 & -0.987656538 & 0.327569184 \\
\hline
\end{tabular}


Table 6. Cont.

\section{(B)}

\section{Event Window $[0,1]$}

\begin{tabular}{|c|c|c|c|c|}
\hline & Coefficients & Standard Error & t Stat & $p$-Value \\
\hline Intercept & -0.000923473 & 0.001628748 & -0.56698311 & 0.572991427 \\
\hline Type (bombing = 1) & -0.002536755 & 0.001575231 & -1.610402172 & 0.11293313 \\
\hline$>1$ target & 0.000991578 & 0.003018085 & 0.328545549 & 0.743724643 \\
\hline Deaths & $4.87653 \times 10^{-5}$ & $5.79168 \times 10^{-5}$ & 0.841988252 & 0.403376045 \\
\hline Wounded & $-9.70598 \times 10^{-6}$ & $7.16219 \times 10^{-6}$ & -1.355168783 & 0.180805112 \\
\hline Target $($ civilian $=1)$ & 0.000232523 & 0.001456084 & 0.159690487 & 0.873699489 \\
\hline Damage (Major $=1$ ) & 0.00132173 & 0.001656648 & 0.79783407 & 0.428337069 \\
\hline \multicolumn{5}{|l|}{ Event Window [0, 2] } \\
\hline & Coefficients & Standard Error & t Stat & $p$-Value \\
\hline Intercept & -0.000852108 & 0.002592858 & -0.32863654 & 0.743656227 \\
\hline Type (bombing $=1$ ) & -0.004380124 * & 0.002507662 & -1.746696419 & 0.086172951 \\
\hline$>1$ target & 0.000157915 & 0.004804589 & 0.032867623 & 0.973897022 \\
\hline Deaths & $9.68882 \times 10^{-5}$ & $9.21996 \times 10^{-5}$ & 1.050852185 & 0.297840233 \\
\hline Wounded & $-1.57836 \times 10^{-5}$ & $1.14017 \times 10^{-5}$ & -1.384318043 & 0.171752959 \\
\hline Target $($ civilian $=1)$ & 0.000214869 & 0.002317989 & 0.092696439 & 0.926475558 \\
\hline Damage $($ Major $=1)$ & 0.002518164 & 0.002637272 & 0.954836551 & 0.343764102 \\
\hline \multicolumn{5}{|l|}{ Event Window $[0,3]$} \\
\hline & Coefficients & Standard Error & t Stat & $p$-Value \\
\hline Intercept & -0.001502862 & 0.003568693 & -0.421124005 & 0.67527649 \\
\hline Type (bombing $=1)$ & $-0.005741943 *$ & 0.003451433 & -1.663640357 & 0.101771341 \\
\hline$>1$ target & 0.003562581 & 0.006612819 & 0.538738625 & 0.592202489 \\
\hline Deaths & $7.46764 \times 10^{-5}$ & 0.000126899 & 0.588468862 & 0.558583732 \\
\hline Wounded & $-1.68185 \times 10^{-5}$ & $1.56928 \times 10^{-5}$ & -1.071732717 & 0.28843726 \\
\hline Target $($ civilian $=1)$ & 0.002083152 & 0.003190375 & 0.652949002 & 0.516460938 \\
\hline Damage (Major = 1) & 0.004709327 & 0.003629823 & 1.297398583 & 0.199813483 \\
\hline \multicolumn{5}{|l|}{ Event Window $[0,4]$} \\
\hline & Coefficients & Standard Error & t Stat & $p$-Value \\
\hline Intercept & -0.002829947 & 0.004048818 & -0.69895623 & 0.487472283 \\
\hline Type (bombing $=1$ ) & $-0.006449173 *$ & 0.003915783 & -1.646968987 & 0.10516537 \\
\hline$>1$ target & -0.000140153 & 0.007502497 & -0.018680816 & 0.985162133 \\
\hline Deaths & 0.000115961 & 0.000143972 & 0.805440927 & 0.423972117 \\
\hline Wounded & $-1.90111 \times 10^{-5}$ & $1.78041 \times 10^{-5}$ & -1.06779316 & 0.290195423 \\
\hline Target $($ civilian $=1)$ & 0.001871742 & 0.003619602 & 0.517112585 & 0.607114089 \\
\hline Damage (Major $=1$ ) & $0.007861658 *$ & 0.004118173 & 1.909015949 & 0.061389237 \\
\hline \multicolumn{5}{|l|}{ Event Window $[0,5]$} \\
\hline & Coefficients & Standard Error & t Stat & $p$-Value \\
\hline Intercept & -0.002321301 & 0.004151967 & -0.55908479 & 0.578332966 \\
\hline Type (bombing $=1$ ) & $-0.008055856^{* *}$ & 0.004015542 & -2.006169018 & 0.049677313 \\
\hline$>1$ target & 0.001124861 & 0.007693632 & 0.146206757 & 0.884283218 \\
\hline Deaths & 0.000137207 & 0.00014764 & 0.929331101 & 0.356706276 \\
\hline Wounded & $-2.34075 \times 10^{-5}$ & $1.82577 \times 10^{-5}$ & -1.282061746 & 0.205103305 \\
\hline Target $($ civilian $=1)$ & 0.001652513 & 0.003711816 & 0.445203433 & 0.657888986 \\
\hline Damage (Major $=1$ ) & 0.007298044 * & 0.004223088 & 1.728129732 & 0.089476052 \\
\hline
\end{tabular}

Notes A: The above table presents cross-sectional regression results for the Euro vs. the Dollar CAR. The dependent variable are the CAR of the event days examined, while the explanatory variables are the type of attack (bombing/explosion or other); the number of targets attacked; the number of dead; the number of wounded; the type of target (civilian or other); and the damage as per the GTD definition (major vs. non-major). The table depicts the coefficient, standard error, t-statistic, and $p$-value for each independent variable; **: significant at 5\%; *: significant at 10\%. Notes B: The above table presents cross-sectional regression results for the Euro vs. the Pound CAR. The dependent variable are the CAR of the event days examined, while the explanatory variables are the type of attack (bombing/explosion or other); the number of targets attacked; the number of dead; the number of wounded; the type of target (civilian or other); and the damage as per the GTD definition (major vs. non-major). The table depicts the coefficient, standard error, t-statistic, and $p$-value for each independent variable. ${ }^{* *}$ : significant at $5 \%$; ${ }^{*}$ significant at $10 \%$. 


\section{Discussion and Conclusions}

This paper employed the event study methodology to examine whether significant terrorist attacks which occurred in the Eurozone over the course of the 21st century affected the price of the common currency. Such an effect was possible through several impact mechanisms: reduced foreign direct investment; reduced trade; less tourists visiting the region; and, of course, the negative psychological effects which often affect markets following such shocking events. More specifically, 63 attack days were selected and an assessment was made to see whether these attacks resulted in significant negative cumulative abnormal returns for the Euro, vs. four other major currencies: the Dollar, the Pound, the Franc, and the Yen. The analysis was carried out over five event windows in an attempt to evaluate whether there was any spillover effect beyond the event day.

Results indicated that such attacks did affect the value of the Euro but the magnitude of this effect was not significant. For example, the maximum negative cumulative abnormal returns that were documented for the EUR vs. the USD was $-0.184 \%$, and vs. the GBP was $-0.20 \%$ (both occurred in the [0,2] event window). Moreover, it appears that the negative returns extended in the days which followed the attack (i.e., there was a spillover effect), but their magnitude was fairly minimal; the maximum negative CAR documented were for the EUR vs. the CHF in the $[0,5]$ event window $(-0.57 \%)$. Generally, results indicated that the price of the Euro seemed to depreciate more vs. the Dollar and the Pound in the first couple of days after the attack, while this depreciation of the Euro vs. the Yen and the Franc was more evident in the latter event windows. For comparative purposes we also carried out additional analysis related to the impact of the $9 / 11$ attack in on the Dollar in the US, and the 7 July 2005 attack on the Pound in the UK. Regarding the first event, our results bore some interesting similarities to our analysis regarding the Euro, as adjustments of the Dollar vs. the Euro and the Pound occurred early on, while the depreciation of the Euro vs. the Yen and the Franc seemed to be cumulatively higher and more persistent. As far as the 7/7 attack is concerned, once again results pointed to some similarities to our analysis, as they validated the Pound adjustment vs. the Euro and also the depreciation of the Euro vs. the safe-haven currencies, in particular the Franc.

Moreover, our results indicated that there appeared to be differing reactions of the Euro vs. the four other currencies between the first and second decades of the 21st century. More specifically, it seemed that the negative CAR of the EUR vs. the USD and the GBP were more evident and significant in the first decade, while the corresponding negative CAR vs. the CHF and the JPY appeared to be stronger in the second decade. The differences were relatively minimal in the cases of the USD, the GBP, and the JPY, but not so minimal for the CHF where, in the second decade, we observed CAR of around $-2.5 \%$ in the latter event windows. Examination of the sub-sample of event days, which included the more severe terror attacks that resulted in deaths, did not reveal any substantially different patterns. On the contrary, the Euro exhibited negative CAR that were significant only vs. the Yen and only in some of the event windows.

It appeared that, with the exception of the CHF in the second sub-period examined, the minimal scale of the reaction of the Euro suggested that the common currency was fairly resilient to the shock of a terror attack. This result implied that investors holding assets denominated in the Euro did not become particularly anxious or sell their assets after such an event. Instead, they seemed to have taken the stance that terror attacks, unlike other events that have long-lasting effects on society and the economy, such as wars and coups, are of a temporary nature, and so their response was limited and without overreaction. A contributing factor to this is surely the democratic governmental systems of Europe, where a publicly elected Government is not likely to risk losing its legitimacy following such an event. Purely from an economic perspective, markets are treating such events as being of an idiosyncratic nature and as such, in most cases, they do not result in any substantial abnormal returns. Our results also seemed to suggest that the potential direct costs related to loss of life after a terror attack did not seem to alter this observation, a rather unfortunate reality. 
Nonetheless, despite this general result, the result related to the Franc (and the Yen to a lesser extent) in the second sub-period could indicate that, by following such attacks, investors may seek safe-haven assets, such as the Franc; as already noted, the Franc and the Yen tend to remain relatively stable in times of turmoil or crisis and hence defend investments from the adverse impacts of currency risk. This result was also supported by the findings from our analysis of the two attacks that occurred outside the Eurozone: 9/11 and its effect on the Dollar and the London bombings of 7 July 2005 and their effect on the Pound.

Another important dimension related to the relatively minimal reaction of the Euro to such events could revolve around the fact that although European Member States, especially the smaller ones, may not possess the monetary and fiscal policy freedoms to support their economies in the case of terror attacks, the European Central Bank (ECB), whose objective is to safeguard the value of the Euro, is likely to do so provided this is necessary. Market participants will remember very well Mario Draghi's statement: 'Within our mandate, the ECB is ready to do whatever it takes to preserve the euro. And believe me, it will be enough ${ }^{7}$ and its effect in calming down markets during the Euro sovereign debt crisis in 2012. Notably, weeks after the November 2015 terror attacks in Paris, the ECB cut interest rates and extended its quantitative-easing program, just like the Fed did after 9/11.

The findings of our work also benefited from regression analysis, used to identify whether specific characteristics of each attack day affected the cumulative abnormal returns of the Euro vs. the four other currencies. In the case of the Euro vs. the Dollar, it appears that attack days which included attacks on more than one target were associated with lower CAR, as were attacks that targeted civilian targets. Moreover, in the case of the Euro vs. the Pound, attacks carried out by bombing or explosions resulted in more negative CAR. There were no significant results in the case of the Franc and the Yen.

In summary, the findings of this study, with a relatively large dataset of terror attacks that occurred in Eurozone countries over the course of the 21st century, implied that, as a general rule, we cannot normally expect such events to substantially decrease the price of the Euro vs. other major currencies. Instead, in most cases, it may lead to a decline of less than $0.5 \%$ which is often not statistically significant. It would appear that investors holding Euro-denominated assets have learned that, unlike the human consequences, the financial ramifications of a terror attack are likely to be short-lived and will not affect economies in the same way as, for example, a recession would; markets are likely to bounce back rather quickly. Having said that, there appears to be some evidence pointing to a diversion to safe-haven currencies such as the Franc and, to a lesser extent the Yen, following the event of a terror attack.

The work carried out in this paper may pave the way for further research on the subject, which could involve examining whether terror attacks increase the volatility (rather than the returns) of the Euro vs. other currencies, or studying the effects of such events on the currencies of developing countries, which may be more vulnerable to terror attacks. It could also involve the use of alternative event-study tools to carry out the analysis, e.g., non-parametric tests. Our findings could also be used in the decision-making process of investors holding Euro-denominated assets who, justifiably, might be concerned about the impact of such events. It seems that terror attacks might not be a good example of 'Knightian uncertainty' after all.

Funding: This research received no external funding.

Data Availability Statement: The data used for the purposes of this study is available upon request from the authors.

Conflicts of Interest: The author declares no conflict of interest. 


\section{Appendix A}

Table A1. List of all "event-days" in our sample.

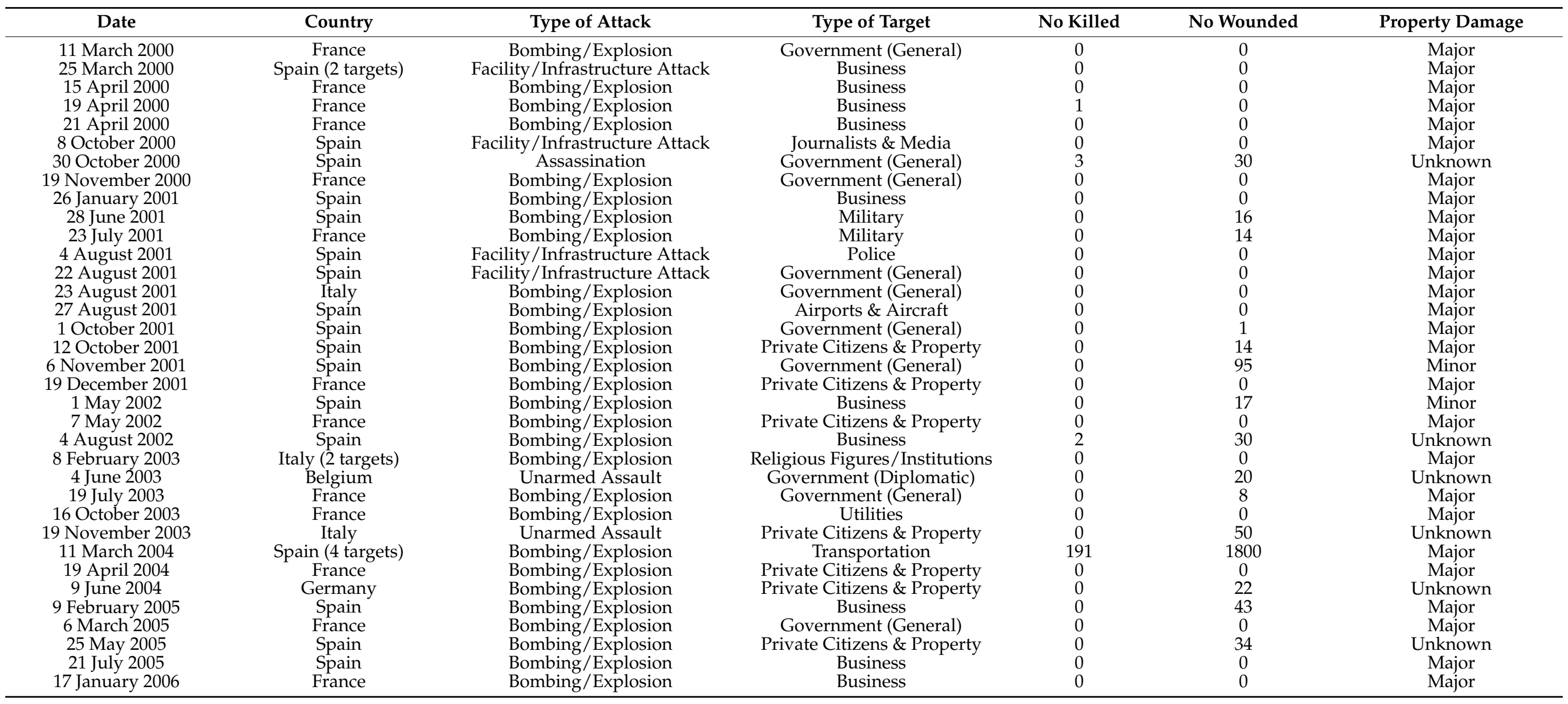


Table A1. Cont.

\begin{tabular}{|c|c|c|c|c|c|c|}
\hline Date & Country & Type of Attack & Type of Target & No Killed & No Wounded & Property Damage \\
\hline 20 January 2006 & France & Bombing/Explosion & Private Citizens \& Property & 0 & 0 & Major \\
\hline 11 May 2006 & France & Bombing/Explosion & Government (General) & 0 & 0 & Major \\
\hline 19 September 2006 & Greece & Bombing/Explosion & Business & 0 & 0 & Major \\
\hline 5 June 2007 & France & Bombing/Explosion & Business & 0 & 0 & Major \\
\hline 11 June 2007 & Finland & Armed Assault & Educational Institution & 9 & 13 & Unknown \\
\hline 7 November 2007 & Spain & Facility/Infrastructure Attack & Transportation & 0 & 0 & Major \\
\hline 21 January 2008 & Greece & Facility/Infrastructure Attack & Business & 0 & 0 & Major \\
\hline 19 May 2008 & Spain & Bombing/Explosion & Business & 0 & 0 & Major \\
\hline 30 October 2008 & France & Bombing/Explosion & Business & 0 & 0 & Major \\
\hline 4 February 2009 & Greece & Facility/Infrastructure Attack & Business & 0 & 0 & Major \\
\hline 23 February 2009 & Spain & Bombing/Explosion & Government (Diplomatic) & 0 & 0 & Major \\
\hline 1 May 2009 & Netherlands & Assassination & Government (General) & 7 & 12 & Minor \\
\hline 29 July 2009 & Spain & Bombing/Explosion & Police & 0 & 46 & Major \\
\hline 22 February 2011 & France & Bombing/Explosion & Business & 0 & 0 & Major \\
\hline 28 September 2014 & Spain & Bombing/Explosion & Transportation & 0 & 0 & Major \\
\hline 7 January 2015 & France & $\begin{array}{l}\text { Hostage Taking (Barricade } \\
\text { Incident) }\end{array}$ & Journalists \& Media & 12 & 12 & Minor \\
\hline 9 January 2015 & France & $\begin{array}{c}\text { Hostage Taking (Barricade } \\
\text { Incident) }\end{array}$ & Business & 5 & 3 & Minor \\
\hline 13 January 2015 & France (6 targets) & $\begin{array}{l}\text { Hostage Taking (Barricade } \\
\text { Incident) }\end{array}$ & Business & 137 & 398 & Minor \\
\hline 10 June 2016 & Finland & Facility/Infrastructure Attack & Transportation & 0 & 0 & Major \\
\hline 14 July 2016 & France & Armed Assault & Private Citizens \& Property & 87 & 433 & Unknown \\
\hline 22 July 2016 & Germany & Armed Assault & Private Citizens \& Property & 10 & 27 & Unknown \\
\hline 24 July 2016 & Germany & Bombing/Explosion & Business & 1 & 15 & Unknown \\
\hline 20 November 2016 & France & Unarmed Assault & Private Citizens \& Property & 0 & 15 & Unknown \\
\hline 19 December 2016 & Germany & Unarmed Assault & Private Citizens \& Property & 12 & 48 & Minor \\
\hline 17 August 2017 & Spain & Unarmed Assault & Private Citizens \& Property & 14 & 101 & Unknown \\
\hline 18 August 2017 & Spain & Armed Assault & Private Citizens \& Property & 6 & 6 & Unknown \\
\hline
\end{tabular}

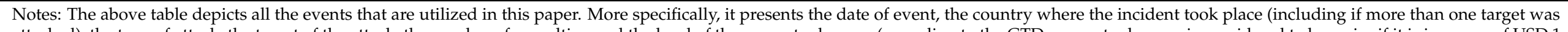

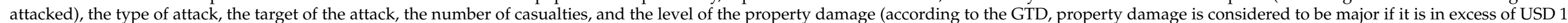

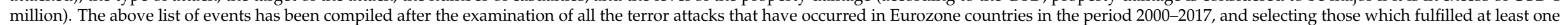
of the following criteria: (a) more than 5 deaths; (b) more than 15 injured; and (c) the property damage was described to be 'major' in economic terms. 


\section{Notes}

1 U.S. Department of State; https:/ / www.state.gov/j/ct/rls/crt/2003/31685.htm (accessed on 5 January 2020).

2 For comparative purposes, we note that the 2017 EU Directive on Terrorism (EU 2017/541) defines terrorist offences as those that aim to seriously intimidate a population; unduly compel a Government or an international organization to perform or abstain from performing any act; or to seriously destabilize or destroy the fundamental political, constitutional, economic or social structures of a country or an international organization (Article 3(2)). Although this definition clearly reflects the fact that terrorism aims to spread fear and inhibit community cohesion through the threat of or execution of acts of violence, in this paper we use the definition provided by the US Government since it is more direct regarding what constitutes a significant incident.

3 The Global Terrorism Database is the most extensive global dataset of terror attacks and is maintained by the National Consortium for the Study of Terrorism and Responses to Terrorism at the University of Maryland, United States. The database is time-stamped by year, month and day.

4 Both of these attacks were carried out by Al-Qaida and, according to the GTD, the first one resulted in 2997 deaths and 7365 injuries and the second one resulted in 56 deaths and 784 injuries.

5 To preserve space, we did not report the full set of results, which nonetheless are available upon request.

6 The Global Terrorism Database defines damage as 'major' in cases where the cost of the damage is greater than USD 1 million.

7 https://www.ecb.europa.eu/press/key/date/2012/html/sp120726.en.html (accessed on 5 January 2020).

\section{References}

Abadie, Alberto, and Javier Gardeazabal. 2003. The Economic Cost of Conflict: A Case Study of the Basque Country. American Economic Review 93: 113-32. [CrossRef]

Abadie, Alberto, and Javier Gardeazabal. 2008. Terrorism and the World Economy. European Economic Review 52: 1-27. [CrossRef]

Arin, K. Peren, Davide Ciferri, and Nicola Spagnolo. 2008. The price of terror: The effects of terrorism on stock market returns and volatility. Economics Letters 101: 164-67. [CrossRef]

Ball, Ray, and Philip Brown. 1968. An Empirical Evaluation of Accounting Income Numbers. Journal of Accounting Research 6: 159-77. [CrossRef]

Ballegooij, Wouter Van, and Piotr Bakowski. 2018. The Fight against Terrorism. Brussels: European Parliamentary Research Service.

Baumert, Thomas. 2009. Terrorism, News Flows and Stock Markets. In Global Business and the Terrorist Threat Cheltenham. Edited by Harry W. Richardson, Peter Gordon and James E. Moore II. Northampton: Elgar, pp. 119-35.

Baumert, Thomas, Mihel Buesa, and Timothy Lynch. 2013. The Impact of Terrorism on Stock Markets: The Boston Bombing Experience in Comparison with Previous Terrorist Events. Documento de Trabajo No. 88. Madrid: Instituto De Analysis Industrial Y Financiero.

Bloomberg, S. Brock, Gregory Hess, and Akila Weerapana. 2004. Economic Conditions and Terrorism. European Journal of Political Economy 20: 463-78. [CrossRef]

Brounen, Dirk, and Jeroen Derwall. 2010. The Impact of Terrorist Attacks on International Stock Markets. European Financial Management 16: 585-98. [CrossRef]

Brown, Stephen J., and Jerold B. Warner. 1980. Measuring Security Price Performance. Journal of Financial Economics 8: 205-58. [CrossRef]

Brück, Tilman, and Bengt-Arne Wickstrom. 2004. The economic consequences of terror. European Journal of Political Economy 20: 293-300. [CrossRef]

Bruner, Robert F. 1999. An analysis of value destruction and recovery in the alliance and proposed merger of Volvo and Renault. Journal of Financial Economics 51: 125-66. [CrossRef]

Chen, Andrew H, and Thomas F. Siems. 2004. The Effects of Terrorism on Global Capital Markets. European Journal of Political Economy 20: 349-66. [CrossRef]

Chesney, Marc, Ganna Reshetar, and Mustafa Karamana. 2011. The impact of terrorism on financial markets: An empirical study. Journal of Banking $\mathcal{E}$ Finance 35: 253-67.

Corbet, Shaen, John F. O'Connell, Marina Efthymiou, Cathal Guiomard, and Brian Lucey. 2019. The impact of terrorism on European tourism. Annals of Tourism Research 75: 1-17. [CrossRef]

Drakos, Konstantinos. 2004. Terrorism-Induced Structural Shifts in Financial Risk: Airline Stocks in the Aftermath of the September 11th Terror Attacks. European Journal of Political Economy 20: 435-46. [CrossRef]

Drakos, Konstantinos, and Ali M. Kutan. 2003. Regional Effects of Terrorism on Tourism: Evidence from Three Mediterranean Countries. Journal of Conflict Resolution 47: 621-41. [CrossRef]

Eldor, Rafi, and Rafi Melnick. 2004. Financial Markets and Terrorism. European Journal of Political Economy 20: 367-86. [CrossRef]

Eldor, Rafi, Shmuel Hauser, Yoram Kroll, and Sharbel Shoukair. 2012. Financial Markets and Terrorism: The Perspective of the Two Sides of the Conflict. Journal of Business Administration Research 1: 18-29. [CrossRef]

Evans, Martin D. D., and Richard K. Lyons. 2008. How is Macro News Transmitted to Exchange Rates? Journal of Financial Economics 88: 26-50. [CrossRef]

Fama, Eugene F. 1970. Efficient Capital Markets: A Review of Theory and Empirical Work. The Journal of Finance 25: 383-417. [CrossRef]

Field, Andy. 2009. Discovering Statistics Using SPSS, 3rd ed. London: Sage Publications Ltd. 
Fleischer, Aliza, and Steven Buccola. 2002. War, Terror and the Tourism Market in Israel. Applied Economics 34: 1335-43. [CrossRef]

Gaibulloev, Khusrav, and Todd Sandler. 2008. Growth Consequences of Terrorism in Western Europe. Kyklos International Review for Social Sciences 61: 411-24. [CrossRef]

Gravetter, Frederick, and Larry Wallnau. 2014. Essentials of Statistics for the Behavioral Sciences, 8th ed. Belmont: Wadsworth.

Hassapis, Christis, Savvas Katsikides, and Stelios Markoulis. 2018. Terror Attacks, Foreign Exchange Markets and Class Dynamics. In Classes-From National to Global Class Formation. London: IntechOpen, pp. 55-75.

Ito, Harumi, and Darin Lee. 2004. Assessing the Impact of the September 11 Terrorist Attacks on U.S. Airline Demand. Journal of Economics and Business 57: 75-95. [CrossRef]

Johnston, R. Barry, and Oana M. Nedelescu. 2005. The Impact of Terrorism on Financial Markets. Working Paper. Washington, DC: International Monetary Fund.

Keown, J. Arthur, and John M. Pinkerton. 1981. Merger announcements and insider trading activity: An empirical investigation. Journal of Finance 36: 855-69. [CrossRef]

Knight, Frank H. 1921. Risk, Uncertainty, and Profit. Boston: Hart, Schaffner \& Marx and Houghton Mifflin Company.

Kollias, Christos, Stephanos Papadamou, and Apostolos Stagiannis. 2011. Terrorism and Capital Markets: The Effects of the Madrid and London Bomb Attacks. International Review of Economics and Finance 20: 532-41. [CrossRef]

Kothari, S. P., and Jerold B. Warner. 2007. Econometrics of Event Studies. In Handbook of Corporate Finance: Empirical Corporate Finance. Amsterdam: Elsevier, pp. 3-36.

Lenain, Patrick, Marcos Bonturi, and Vincent Koen. 2002. The Economic Consequences of Terrorism. OECD Economics Department Working Papers No. 334. Paris: OECD Publishing.

Loughran, Tim, and Jay R. Ritter. 1995. The New Issues Puzzle. Journal of Finance 50: 23-51. [CrossRef]

MacKinlay, A. Craig. 1997. Event Studies in Economics and Finance. Journal of Economic Literature 35: 13-39.

Maitah, Mansoor, Jehar Mustofa, and Gok Ugur. 2017. The Impact of Terrorist Attacks on Foreign Exchange Rate: Case Study of Turkish Lira versus Pound Sterling. Economies 5: 5. [CrossRef]

Markoulis, Stelios, and Nikolas Neofytou. 2019. The impact of terror attacks on global sectoral capital markets: An empirical study. The Economics of Peace and Security Journal 14: 46-59. [CrossRef]

Markoulis, Stelios, and Savvas Katsikides. 2018. The Effect of Terrorism on Stock Markets: Evidence from the 21st Century. Terrorism and Political Violence 32: 988-1010. [CrossRef]

Narayan, Paresh Kumar, Seema Narayan, Siroos Khademalomoom, and Dinh Hoang Bach Phan. 2017. Do terrorist attacks impact exchange rate behavior? New international evidence. Economic Inquiry 56: 547-61. [CrossRef]

Nitsch, Volker, and Dieter Schumacher. 2004. Terrorism and international trade: An empirical investigation. European Journal of Political Economy 20: 423-33. [CrossRef]

Papakyriakou, Panayiotis, Athansios Sakkas, and Zenon Taoushanis. 2019. The impact of terrorist attacks in G7 countries on international stock markets and the role of investor sentiment. Journal of International Financial Markets, Institutions and Money 61: 143-60. [CrossRef]

Park, Jin Suk, and Newaz Mohammad Khaleq. 2018. Do terrorist attacks harm financial markets? A meta-analysis of event studies and the determinants of adverse impact. Global Finance Journal 37: 227-47. [CrossRef]

Pham, Cong S., and Chris Doucouliagos. 2017. An Injury to One Is an Injury to All: Terrorism's Spillover Effects on Bilateral Trade. IZA Discussion Papers No. 10859. Bonn: IZA-Institute of Labor Economics.

Raby, Geoff. 2003. The Costs of Terrorism and the Benefits of Cooperating to Combat Terrorism. Paper presented at Department of Foreign Affairs and Trade to APEC Senior Officials Meeting, Chiang Rai, Thailand, February 21.

Rendleman, Richard, Charles P. Jones, and Henry A. Latane. 1982. Empirical anomalies based on unexpected earnings and the importance of risk adjustments. Journal of Financial Economics 10: 269-87. [CrossRef]

Schneider, Friedrich, Tilman Bruck, and Daniel Meierrieks. 2014. The economics of counter-terrorism: A survey. Journal of Economic Surveys 29: 131-57. [CrossRef]

Schwert, G. William. 1981. Using Financial Data to Measure Effects of Regulation. Journal of Law and Economics 24: 121-58. [CrossRef]

Sloboda, Brain W. 2003. Assessing the Effects of Terrorism on Tourism by Use of Time Series Methods. Tourism Economics 9: 179-90. [CrossRef]

Teoh, Siew Hong, Ivo Welch, and T. J. Wong. 1998a. Earnings management and the long-run market performance of initial public offerings. Journal of Finance 53: 1935-74. [CrossRef]

Teoh, Siew Hong, Ivo Welch, and T. J. Wong. 1998b. Earnings management and the underperformance of seasoned equity offerings. Journal of Financial Economics 50: 63-99. [CrossRef]

Trochim, William M. K., and James P. Donnelly. 2006. The Research Methods Knowledge Base, 3rd ed. Cincinnati: Atomic Dog. 